comptes rendus
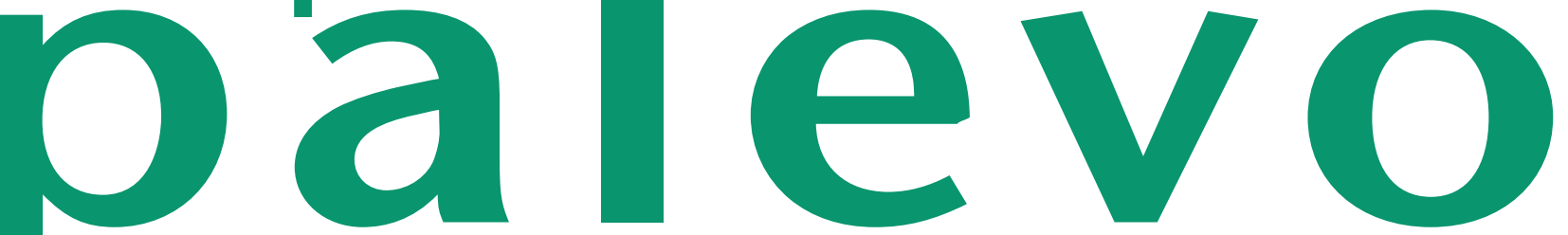

$2021 \cdot 20 \cdot 31$

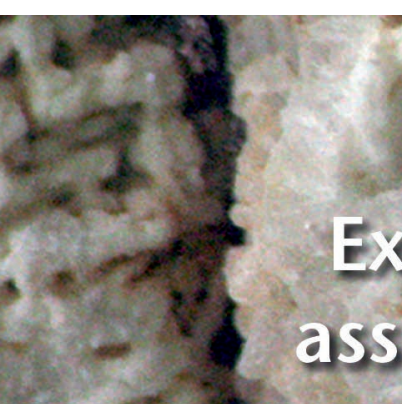

Exceptionally preserved callefited sponige assemblages in Upper Jurabsic carborates of the eastern Getic Carbonate Platform (Southern Carpathians, Bo mania)

George PIES, Felix SCHLAGINTWEIT, Iuliana LAZAR, loan.. BUCUR, Emanoil SASARAN \& Mihaela GRADINARU 
DiRECTEURS DE LA PUBLICATION / PUBLICATION DIRECTORS:

Bruno David, Président du Muséum national d'Histoire naturelle

Étienne Ghys, Secrétaire perpétuel de l'Académie des sciences

RÉDACTEURS EN CHEF / EDITORS-IN-CHIEF: Michel Laurin (CNRS), Philippe Taquet (Académie des sciences)

AssistANTE DE RÉDACTION / AssistANT EDITOR: Adenise Lopes (Académie des sciences; cr-palevol@academie-sciences.fr)

MISE EN PAGE / PAGE LAYOUt: Audrina Neveu (Muséum national d'Histoire naturelle; audrina.neveu@mnhn.fr)

RÉVISIONS LINGUISTIQUES DES TEXTES ANGLAIS / ENGLISH LANGUAGE REVISIONS: Kevin Padian (University of California at Berkeley)

RÉDACTEURS ASSOCIÉS / ASSOCIATE EDITORS ( ${ }^{*}$, took charge of the editorial process of the article/a pris en charge le suivi éditorial de l'article):

Micropaléontologie/Micropalaeontology

Maria Rose Petrizzo (Università di Milano, Milano)

Paléobotanique/Palaeobotany

Cyrille Prestianni (Royal Belgian Institute of Natural Sciences, Brussels)

Métazoaires/Metazoa

Annalisa Ferretti* (Università di Modena e Reggio Emilia, Modena)

Paléoichthyologie/Palaeoichthyology

Philippe Janvier (Muséum national d'Histoire naturelle, Académie des sciences, Paris)

Amniotes du Mésozoïque/Mesozoic amniotes

Hans-Dieter Sues (Smithsonian National Museum of Natural History, Washington)

Tortues/Turtles

Juliana Sterli (CONICET, Museo Paleontológico Egidio Feruglio, Trelew)

Lépidosauromorphes/Lepidosauromorphs

Hussam Zaher (Universidade de São Paulo)

Oiseaux/Birds

Eric Buffetaut (CNRS, École Normale Supérieure, Paris)

Paléomammalogie (mammifères de moyenne et grande taille)/Palaeomammalogy (large and mid-sized mammals)

Lorenzo Rook (Università degli Studi di Firenze, Firenze)

Paléomammalogie (petits mammifères sauf Euarchontoglires)/Palaeomammalogy (small mammals except for Euarchontoglires)

Robert Asher (Cambridge University, Cambridge)

Paléomammalogie (Euarchontoglires)/Palaeomammalogy (Euarchontoglires)

K. Christopher Beard (University of Kansas, Lawrence)

Paléoanthropologie/Palaeoanthropology

Roberto Macchiarelli (Université de Poitiers, Poitiers)

Archéologie préhistorique/Prehistoric archaeology

Marcel Otte (Université de Liège, Liège)

RÉFÉRÉS / REVIEWERS: https://sciencepress.mnhn.fr/fr/periodiques/comptes-rendus-palevol/referes-du-journal

COUVERTURE / COVER:

Made from the Figures of the article.

Comptes Rendus Palevol est indexé dans / Comptes Rendus Palevol is indexed by:

- Cambridge Scientific Abstracts

- Current Contents ${ }^{\circledR}$ Physical

- Chemical, and Earth Sciences ${ }^{\circledR}$

- ISI Alerting Services ${ }^{\circledR}$

- Geoabstracts, Geobase, Georef, Inspec, Pascal

- Science Citation Index ${ }^{\circledR}$, Science Citation Index Expanded ${ }^{\circledR}$

- Scopus ${ }^{\circledR}$.

Les articles ainsi que les nouveautés nomenclaturales publiés dans Comptes Rendus Palevol sont référencés par / Articles and nomenclatural novelties published in Comptes Rendus Palevol are registered on:

- ZooBank ${ }^{\circledR}$ (http://zoobank.org)

Comptes Rendus Palevol est une revue en flux continu publiée par les Publications scientifiques du Muséum, Paris et l'Académie des sciences, Paris Comptes Rendus Palevol is a fast track journal published by the Museum Science Press, Paris and the Académie des sciences, Paris

Les Publications scientifiques du Muséum publient aussi / The Museum Science Press also publish:

Adansonia, Geodiversitas, Zoosystema, Anthropozoologica, European Journal of Taxonomy, Naturae, Cryptogamie sous-sections Algologie, Bryologie, Mycologie.

L'Académie des sciences publie aussi / The Académie des sciences also publishes:

Comptes Rendus Mathématique, Comptes Rendus Physique, Comptes Rendus Mécanique, Comptes Rendus Chimie, Comptes Rendus Géoscience, Comptes Rendus Biologies.

Diffusion - Publications scientifiques Muséum national d'Histoire naturelle

CP 41 - 57 rue Cuvier F-75231 Paris cedex 05 (France)

Tél. : 33 (0)1 40794805 / Fax: 33 (0)1 40793840

diff.pub@mnhn.fr / https://sciencepress.mnhn.f

Académie des sciences, Institut de France, 23 quai de Conti, 75006 Paris.

(C) Publications scientifiques du Muséum national d'Histoire naturelle / @ Académie des sciences, Paris, 2021

ISSN (imprimé / print): 1631-0683/ ISSN (électronique / electronic): 1777-571X 


\section{Exceptionally preserved calcified sponge assemblages in Upper Jurassic carbonates of the eastern Getic Carbonate Platform (Southern Carpathians, Romania)}

George PLEŞ
Department of Geology and Center for Integrated Geological Studies,
Babeş-Bolyai University, 1 Mihail Kogălniceanu, 400084 Cluj-Napoca (Romania)
george.ples@ubbcluj.ro (corresponding author)
Felix SCHLAGINTWEIT
Lerchenauerstr. 167, 80935 Munich (Germany)
felix.schlagintweit@gmx.de
Iuliana LAZĂR
Department of Geology, University of Bucharest,
1 Nicolae Bălcescu, 010041 Bucharest (Romania)
iuliana.lazar@g.unibuc.ro

loan I. BUCUR

Emanoil SĂSĂRAN

Department of Geology and Center for Integrated Geological Studies, Babeş-Bolyai University, 1 Mihail Kogălniceanu, 400084 Cluj-Napoca (Romania) ioan.bucur@ubbcluj.ro emanoil.sasaran@ubbcluj.ro

Mihaela GRĂDINARU Department of Geology, University of Bucharest, 1 Nicolae Bălcescu, 010041 Bucharest (Romania) mihaela.gradinaru@unibuc.ro

Pleş G., Schlagintweit F., Lazăr I., Bucur I. I., Săsăran E. \& Grădinaru M. 2021. - Exceptionally preserved calcified sponge assemblages in Upper Jurassic carbonates of the eastern Getic Carbonate Platform (Southern Carpathians, Romania). Comptes Rendus Palevol 20 (31): 641-666. https://doi.org/10.5852/cr-palevol2021v20a31

\section{ABSTRACT}

A rich poriferan assemblage was identified within the easternmost part of the Getic Carbonate Platform of Romania (Grădiștei Gorges). The excellent preservation state of most poriferans here led to the discovery of a new species (Neuropora gigantea Pleș \& Schlagintweit, n. sp.) and to the identification of previously unknown diagnostic features in some species (Sarsteinia babai Schlagintweit \& Gawlick, 2006 emend., Neuropora lusitanica Termier, 1985, Sphaeractinia steinmanni Canavari, 1893). Calciagglutispongia yabei Reitner, 1992, Sarsteinia babai and Sphaeractinia steinmanni are reported 
KEY WORDS

Calcified sponges,

microencrusters, carbonate platforms, Intra-Tethyan realm, reef zonation, palaeoenvironments, palaeoecology, taphonomy,

KimmeridgianTithonian, new species.

MOTS CLÉS Éponges calcifiées, micro-organismes encroûtants, plateformes carbonatées, domaine intra-téthysien, zonation récifale, paléoenvironnements, paléoécologie, taphonomie, KimméridgienTitonique espèce nouvelle. for the first time from the Upper Jurassic carbonates of the Getic Carbonate Platform. The sedimentary input fluctuations and the nutrient competition had an important role in understanding the morphological adaptations of the analysed species. The existing palaeoecological and palaeoenvironmental conditions generated different distribution patterns towards the reef profile and also preferential adaptations to a specific Tethyan domain. As opposed to the poriferan assemblages from the northern Tethyan shelves, these organisms formed sponge-coral-microencruster boundstones at the margins and fore-reefal zones of isolated carbonate platforms within the intra-Tethyan realm. The importance of calcified sponges in reef-zonation is highlighted by the establishment of a general zonation model. Three zones can be distinguished: 1) Cladocoropsis-Milleporidium zone (back-reef area); 2) BauneiaChaetetopsis-Parastromatopora zone (central reef area); and 3) SphaeractinialEllipsactinia-Neuropora zone for the fore-reef area. In the absence of a true reef framework these calcified sponges developed typical morphologies, environmental adaptations and partnerships with other biotic groups which strongly influenced the carbonate production throughout the intra-Tethyan domain.

\section{RÉSUMÉ}

Assemblage d'éponges calcifiées exceptionnellement conservées dans les carbonates du Jurassique supérieur de la plateforme gétique carbonatée orientale (Carpates méridionales, Roumanie). Implications paléontologiques et paléoécologiques, caractéristiques taphonomiques et aperçu sur la zonation récifale.

Un assemblage riche en spongiaires a été identifié dans la partie la plus orientale de la plateforme gétique carbonatée de Roumanie (gorges Gradistei). L'excellent état de conservation de la plupart des spongiaires a conduit à la découverte d'une nouvelle espèce (Neuropora gigantea Ples \& Schlagintweit, n. sp.) et à l'identification de caractéristiques diagnostiques, jusque-là inconnues, dans certaines espèces (Sarsteinia babai Schlagintweit \& Gawlick, 2006 emend., Neuropora lusitanica Termier, 1985, Sphaeractinia steinmanni Canavari, 1893). Calciagglutispongia yabei Reitner, 1992, Sarsteinia babai et Sphaeractinia steinmanni ont été signalées pour la première fois dans les carbonates du Jurassique supérieur de la plateforme gétique carbonatée. Les fluctuations des apports sédimentaires et la composition en éléments nutritifs ont eu un rôle important dans la comprehension des adaptations morphologiques des espèces analysées. Les conditions paléoécologiques et paléoenvironnementales existantes ont généré différents patrons de distribution vers le profil récifal et aussi des adaptations préférentielles vers un domaine téthysien spécifique. Contrairement aux assemblages de spongiaires des hauts-fonds nord-téthysiens, ces organismes ont formé des boundstones éponge-corail-élément microencroûtant, aux marges et dans les zones d'avant-récif de plateformes carbonatées isolées au sein du domaine intra-téthysien. L'importance des éponges calcifiées dans la zonation récifale a été soulignée par l'établissement d'un modèle général de zonation. Trois zones peuvent être distinguées : 1) zone à Cladocoropsis-Milleporidium (zone d'arrière-récif); 2) zone à Bauneia-Chaetetopsis-Parastromatopora (zone récifale centrale); et 3) zone à Sphaeractinial Ellipsactinia-Neuropora (zone d'avant-récif). En l'absence d'une vraie construction récifale, ces éponges calcifiées ont développé des morphologies typiques, des adaptations environnementales et des partenariats avec d'autres groupes biologiques, qui ont fortement influencé la formation des carbonates dans tout le domaine intra-téthysien.

\section{INTRODUCTION}

Calcified sponges (e.g. "stromatoporoids") played an important role in the development and evolution of intra-Tethyan platform margin reef systems during the Late Jurassic (e.g. Turnšek et al. 1981; Leinfelder $e t$ al. 2005; Rusciadelli et al. 2011). Together with corals and encrusting organisms, they formed specialized bioconstructed frameworks which produced and consolidated the shallow-water sediments of numerous isolated carbonate platforms. Even though many studies focused on anthozoan distribution (Turnšek et al. 1981; Kołodziej 2015) or encrusting organisms (Schlagintweit \& Gawlick 2008; Pleș et al. 2013; Kaya \& Altiner 2015), little is known about species diversity, morphostructural adaptations and palaeoecological significance of the associated sponge assemblages (Leinfelder et al. 2005).
The present study focuses on the description and analysis of a rich and exceptionally preserved poriferan assemblage discovered in the Dâmbovicioara region (eastern part of the Getic Carbonate Platform, Romania) in order to highlight new palaeontological, palaeoecological and palaeoenvironmental features. The poriferan response to the palaeoenvironment is reflected by their growth patterns (low-domical, encrusting, and rarely, cylindrical). Moreover, the sedimentary input fluctuations and the nutrient competition had an important role in understanding the morphological adaptations of some sponges here. The existing palaeoecological and palaeoenvironmental conditions generated different distributional patterns towards the reef profile and also preferential adaptations to specific Tethyan domains. All of these can be used to establish a general distribution model which may emphasize relationships or discrepancies with synchronous reef types 
in the Tethyan realm. Moreover, the obtained data can serve as a supplementary proxy in understanding the zonation pattern of such bioherms.

\section{CALCIFIED SPONGE ASSEMBLAGES WITHIN THE UPPER JURASSIC TETHYAN REEF SYSTEMS. A SHORT OVERVIEW}

It is well known that Upper Jurassic Tethyan reef systems vary in structural morphology, biotic content and spatial distribution (Leinfelder et al. 1994, 2002; Wood 1999; Leinfelder 2001). A valuable amount of data regarding poriferan-dominated reefs comes from the northern Tethyan carbonates of Portugal (Termier et al. 1985; Nose \& Leinfelder 1997), Spain (Leinfelder et al. 1994), France (Olivier et al. 2004; Leinfelder et al. 2005) or southern Germany (Leinfelder 1993). They are defined most commonly by siliceous sponge-microbialite mud-mounds (mostly during Oxfordian-Kimmeridgian) or by massive coral reefs (framestones) associated with stromatoporids (Leinfelder 2001; Leinfelder et al. 2005). As opposed to these northern Tethyan reefs, the analysed sponge assemblage is associated with corals and various amounts of encrusting morphotypes and syndepositional early cements characterising smaller bioherms developed in epicontinental agitated seas within the intra-Tethyan realm. In the geological literature of the last decade, such deposits are generally known as "microencruster-cement boundstones" (with associated "stromatoporoids") (sensu Schlagintweit \& Gawlick 2008) or "coral-stromatoporoid-microencruster boundstones" (sensu Pleș et al. 2016).

Concerning the "stromatoporoid" skeletal organization of these sponges, it is true that most analysed taxa share such features, but without critical taxonomic elements (e.g. spicules), terms such as "calcareous sponges" or "calcified sponges" are more suitable. The majority of Jurassic poriferans (with or without a stromatoporoid bauplan) are now considered hypercalcified demosponges (West 2011). The chambered sponges are included in the Sphinctozoa group, while those without chambers are part of the Inozoa group of the demosponges (Senowbari-Daryan \& Rigby 2011). More details on this topic can be found in the studies of Reitner (1992), Leinfelder et al. (2005) or West (2011).

\section{GEOLOGICAL SETTING}

The Piatra Craiului-Dâmbovicioara region is situated in the eastern part of the Southern Carpathians between the Iezer-Păpușa (west) and Bucegi and Leaota massifs to the east/south-east. The eastern part of this region comprises a sedimentary sequence made up of Lower-Middle Triassic, Middle-Upper Jurassic and Cretaceous deposits known in the Romanian literature as the "Brașov Series" (Patrulius 1969; Pleș et al. 2013; Mircescu et al. 2016). The studied area is located in the southeastern part (Fig. 1) where only Jurassic and Cretaceous deposits are outcropping. Lithologicaly, the mid-Jurassic deposits (Bajocian-?lower Callovian) are represented by a condensed sequence of sandstones, microconglomerates, marls, sandy and bioclastic limestones with frequent hardground surfaces (Bucur et al. 2011; Lazăr et al. 2013; Grădinaru et al. 2016; Mircescu et al. 2016). The mid-upper Callovian-Oxfordian is defined by the presence of fine layered limestones with radiolarians and cherty nodules (Beccaro \& Lazăr 2007). On top of these deposits, a regressive succession is recorded starting with the Kimmeridgian up to the lower Valanginian characterized mainly by shallowwater carbonates. It corresponds with the eastern domain of the Getic Carbonate Platform comprising platform-margin deposits (slope, fore reef and coral-microencruster buildups) which gradually shift upward into inner-platform carbonates (Bucur 1978; Panaiotu et al. 1997; Dragastan 2010; Bucur et al. 2011; Ples et al. 2013; Mircescu et al. 2016). Starting with the middle Valanginian up to the ?upper Valanginian, a regional discontinuity (hardground) surface is reported from several zones within the Dâmbovicioara area (Patrulius 1969; Patrulius \& Avram 1976; Ungureanu et al. 2015, 2017; Grădinaru et al. 2016). Upper Valanginian hemipelagic carbonates (Cetatea Neamțului Member) are transgressively overlying the middle Valanginian discontinuity followed by uppermost Valanginian-Hauterivian marls with ammonites (Dealu Sasului Member) (Patrulius 1976; Bucur et al. 2011; Grădinaru et al. 2016). The Lower Cretaceous sedimentary sequence continues with Barremian-lower Aptian cephalopod rich marls supporting in the lower part bioconstructed levels (patch-reefs) with corals, calcified sponges, calcareous algae and rudists (Valea Muierii Member) (Patrulius 1969; Bucur et al. 2011). The whole upper Valanginian-lower Aptian succession with all of the three members (Cetatea Neamțului Member, Dealu Sasului Member and Valea Muierii Member) was described as Dâmbovicioara Formation (Patrulius 1969, 1976; Patrulius \& Avram 1976). At the end of the Lower Cretaceous the region is covered by upper Aptian and uppermost AlbianCenomanian polymictic conglomerates (Patrulius 1969; Ungureanu et al. 2017). The sponge assemblage described here, was found in Upper Jurassic carbonates belonging to the Giuvala Formation (Urdărița Member) of the Dâmbovița Group (Dragastan 2010).

\section{SAMPLED SECTION AND METHODOLOGY}

The sponge assemblage was identified in a small outcrop located in the central part of the Grădiștei Gorges touristic complex (Brașov County) (GPS: 4527’2.993”N, 2517’46.363"E; altitude: $1257 \mathrm{~m}$ ) (Fig. 1). The outcrop is represented by a thick pile of massive white-yellowish carbonates (in some parts fractured or breccified) with an impressive palaeontological content charaterized by a variety of calcified sponges and coral fragments (Fig. 2A-F). The excellent taphonomical conditions of most sponge specimens allowed selective sampling and macroscopical observations (biometric features, high resolution photographs). A number of 65 samples were collected from 


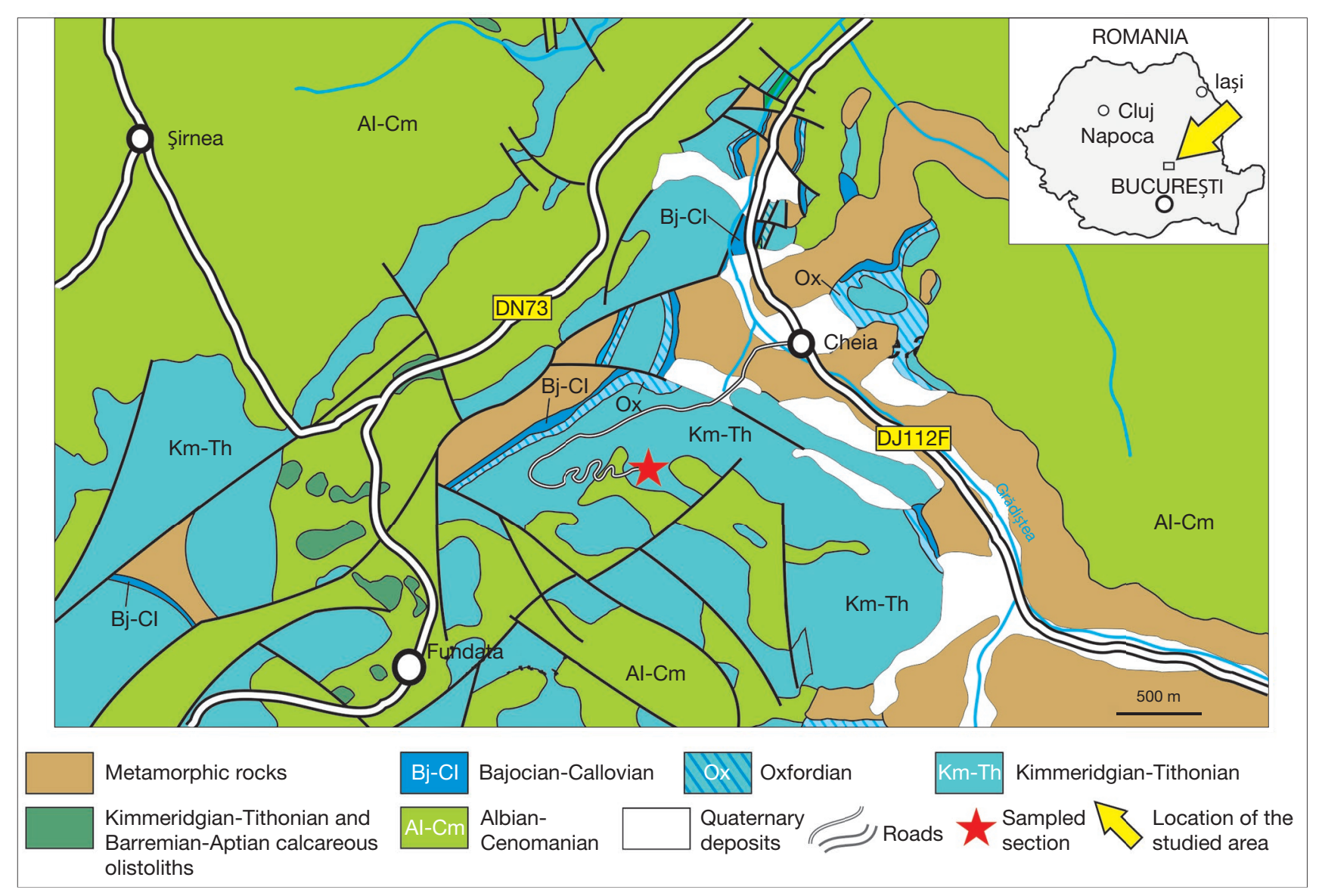

FIG. 1. - Geological map of the studied region based on Dimitrescu et al. (1971, 1974), Patrulius et al. (1971).

this outcrop from which more than 100 thin-sections were made. The samples containing well preserved specimens were cut in different planes (longitudinal, oblique, cross, tangential) in order to obtain a three-dimensional perspective of the skeletal inner-architecture, microstructural features and also for understanding the depositional palaeonvironment. The description, nomenclature and systematics of the calcareous sponges follows Milan (1969), Wood (1987), Reitner (1992), West (2011), Senowbari-Daryan \& Rigby (2011) and West et al. (2013). The classification of the microfacies traits follows Dunham (1962), Embry \& Klovan (1971) and Flügel (2010). The thin-sections used for illustrations are stored at the Geology-Paleontology Museum, Department of Geology, Babeş-Bolyai University in Cluj-Napoca under repository numbers 24127-24155.

\section{RESULTS}

\section{AGE CONSTRAINTS}

Based on the biotic content and lithological traits (e.g. massive appearance) the sampled carbonates from Grădiștei Gorges Complex can be described as Upper Jurassic "Štramberk”-type limestones (sensu Ciborowski \& Kołodziej 2001) or "Plassen"-type limestones (sensu Schlagintweit \& Gawlick 2008). Their age, Kimmeridgian-Tithonian, was established in respect with the existing palaeontological assemblage (calcareous algae, benthic foraminifera, calcified sponges and encrusting microorganisms) corroborated with biostratigraphic data from other studies on similar deposits in this region (Patrulius 1969; Dragastan 2010; Bucur et al. 2011; Mircescu et al. 2016).

Concerning these, the identified palaeontological assemblage consists of the following taxa: foraminifera - Mohlerina basiliensis (Mohler, 1938), Coscinophragma cribrosa (Reuss, 1846), Lituola baculiformis Schlagintweit \& Gawlick, 2009, Lenticulina sp. -; green algae - Salpingoporella pygmaea (Gümbel), Nipponophycus ramosus Yabe \& Toyama, Griphoporella sp. -; calcified sponges - Neuropora lusitanica Termier, 1825, Sphaeractinia steinmanni Canavari, 1893, Ellipsactinia sp., Sarsteinia babai Schlagintweit \& Gawlick, 2006 emend., Perturbatacrusta leini Schlagintweit \& Gawlick, 2011, Thalamopora lusitanica Termier, Termier \& Ramalho, 1985, Calcistella jachenhausenensis Reitner, 1992, Calciagglutispongia yabei Reitner, 1992, Cylicopsis verticalis Turnšek, 1968, Tubuliella sp. -; microencrusters - Crescentiella morronensis (Crescenti, 1969), Labes atramentosa Eliášová, 1986, Radiomura cautica Senowbari-Daryan \& Schäfer, 1979, Koskinobullina socialis Cherchi \& Schroeder, 1979, Thaumatoporella parvovesiculifera (Raineri, 1922) and Lithocodium-type structures -; annelid tubes - Terebella lapilloides Münster, 1833. 

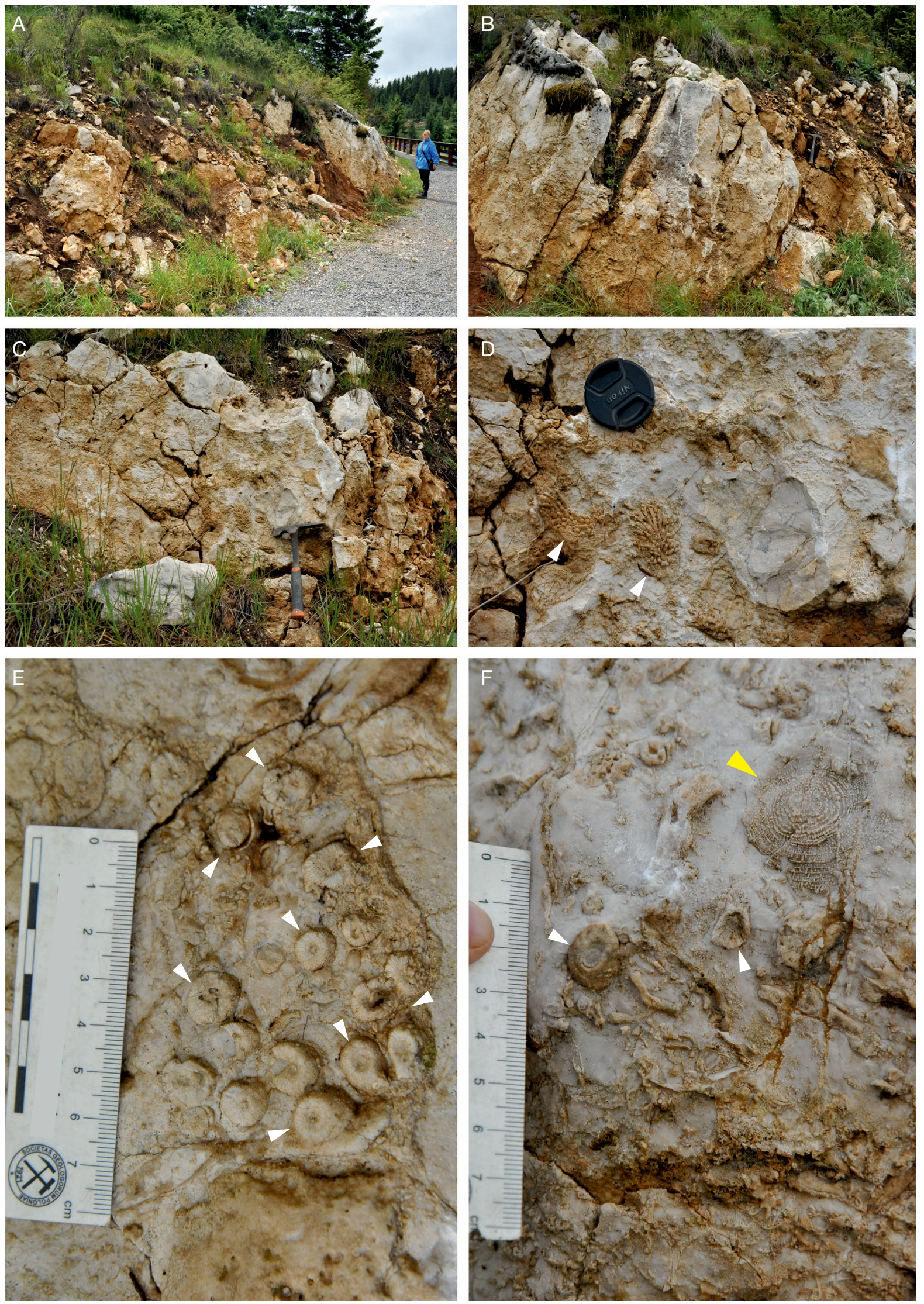

FIG. 2. - Field pictures from the Grădiștei Gorges touristic complex: A-C, massive white-yellowish bioclastic limestones with calcareous sponges and corals; D, coral fragments (white arrows) in reef debris deposits; E, large Neuropora gigantea Pleș \& Schlagintweit, n. sp. agglomeration (white arrows) and microbial crusts (upper-right side of the picture); F, bioclastic rudstone with Neuropora Bronn, 1825 (white arrows), Sphaeractinia Steinmann, 1878 (yellow arrow), bivalves and small coral fragments. 
Mohlerina basiliensis (Fig. 3A) and Lituola baculiformis represent two widely distributed foraminifera species in the Upper Jurassic (Kimmeridgian-Tithonian) intra-Tethyan shallow-water carbonates of Europe (Săsăran et al. 2001; Schlagintweit et al. 2005; Săsăran 2006; Krajewski \& Olszewska 2006; Schlagintweit \& Gawlick 2008, 2009; Bucur et al. 2011; Schlagintweit 2012; Pleș et al. 2013; Mircescu et al. 2014, 2016; Pleș et al. 2016; Atasoy et al. 2018). Regarding the calcareous algae, Salpingoporella pygmaea (Fig. 3B), Nipponophycus ramosus (Fig. 3C) and Griphoporella (Fig. 3D) represent also cosmopolitan species in Kimmeridgian-Tithonian deposits of the Tethyan realm (Granier \& Deloffre 1993; Bucur 1999; Schlagintweit \& Ebli 1999; Bucur \& Săsăran 2005; Schlagintweit 2011). Also, the rich calcified sponge assemblage associated with the microencruster consortium confirms a Kimmeridgian-Tithonian age (details regarding the stratigraphic range of the main poriferan species are given in the description chapter). Even if some sponges and microencrusters - e.g. Crescentiella morronensis (Fig. 3I), Labes atramentosa (Fig. 3F), Radiomura cautica (Fig. 3G), Thaumatoporella parvovesiculifera (Fig. 3E) have a wider stratigraphic range (Schlagintweit et al. 2005 and Pleș et al. 2013, 2017 for details), an acme period in the Upper Jurassic is given by most authors (Ivanova et al. 2008; Schlagintweit \& Gawlick 2008; Kaya \& Altiner 2015). The annelid Terebella lapilloides was identified in Kimmeridgian-Tithonian deposits from northern Turkey (Kaya \& Altiner 2014).

\section{MiCROFACIES AND PALAEOENVIRONMENT}

Bio-intraclastic grainstone/rudstone (MFT1) and spongecoral-microencruster boundstone (MFT2) represent the main microfacies types for the studied carbonates. Details regarding the main components, diagenetic features and other microfacies features are given in Table 1.

Based on the main microfacies traits (Table 1), an agitated platform margin (upper slope/fore-reef) palaeoenvironment is considered. Concerning the bio-intraclastic grainstones/ rudstones (MFT1), these deposits represent most probably small debris-flows composed of abraded particles from the bioconstructed framework generated by a relatively high hydrodynamic regime. This is supported by the diversified microencruster consortium and synsedimentary cement crusts (fibrous or radiaxial cements) which are known to be abundant in these parts of a carbonate platform (Schlagintweit \& Gawlick 2008; Flügel 2010). Moreover, poriferan species such as Ellipsactinia, Sphaeractinia, Neuropora and the foraminifer Lenticulina are prefering such environments (Leinfelder et al. 2005; Rusciadelli et al. 2011; Pleș et al. 2015). The sponge-coral-microencruster boundstone (MFT2) is represented by small buildups without a true reef framework alternating with skeletal debris levels (MFT1). Such peculiarity is typical for the Upper Jurassic intra-Tethyan platform margin reef settings. Here, these bioconstructions did not achieve a high topographic relief (displaying mostly patch-reef characteristics), but the encrusting potential of most of the main components helped to enforce and stabilize the upper slope carbonates.

\section{SYSTEMATIC PALEONTOLOGY}

This chapter focuses on the description of the main calcified sponge taxa which were observed within the Grădiștei Gorges Complex carbonates. Prior to biostratinomic and diagenetic processes in most of the fossil hypercalcified sponges only the calcareous skeleton is preserved and, in some cases, spicules (West 2011). Considering the present agitated palaeoenvironment (fore-reef) the overall preservation state of the sponge skeletons is highly favourable for numerous insights regarding both external and internal morphostructural features, growth patterns and diagnostic traits. As known from previous studies on similar associations (Reitner 1992; Leinfelder et al. 2005; West 2011), Upper Jurassic stromatoporoid- and chaetetid-type poriferans rarely display preserved spicules or did not possess them at all. Based on this statement, it is hard in some species to place an exact phylogenetic position since the spicules represent a critical systematic trait (Wood 1987; Reitner 1992; West 2011). Comments on this topic are given for each analysed species.

\section{Genus Neuropora Bronn, 1825}

\section{Neuropora lusitanica Termier, 1985}

(Fig. 5A, B)

Neuropora lusitanica Termier et al., 1985: 207, pl. 5, figs 1-2. Krajewski \& Schlagintweit 2018: 9, fig. 6a-f.

\section{GENERAL DESCRIPTION}

The internal morphology of Neuropora lusitanica is related to a central tubular system (with more or less parallel longitudinal tubes) from which bifurcating radially arranged tubules are developing perpendicular (or bended) towards the skeleton outer wall. In longitudinal sections, the lateral elements (tubules) resemble a conically superimposed arrangement divided by thin tabulae (Fig. 5A). According to Termier et al. (1985) the septate walls are developing at relatively specific intervals and the peripheral openings of the lateral tubes are characterized by a "crown of spiculous tubercles". In analogy with other Neuropora species, $N$. lusitanica can possess astrorhizae/stellate-type or mamelonar microstructures at the surface of the skeleton (West et al. 2013). The skeleton has a fibrous microstructure best observed in longitudinal and oblique/longitudinal sections.

\section{REMARKS}

This calcified sponge represents a cosmopolitan species among the Upper Jurassic-Lower Cretaceous shallow water reefal and peri-reefal biotic communities of the Getic Carbonate Platform (Pleș et al. 2013, 2016) and throughout synchronous rimmed carbonate platforms of the Tethyan domain (Schlagintweit \& Ebli 1999; Leinfelder et al. 2005; Schlagintweit \& Gawlick 2008). Termier et al. (1985) observed two morphologies in the type-material: 1) an "encrusting" (massive) form with an undifferentiated thickened outer (external) part; and 2) a much 

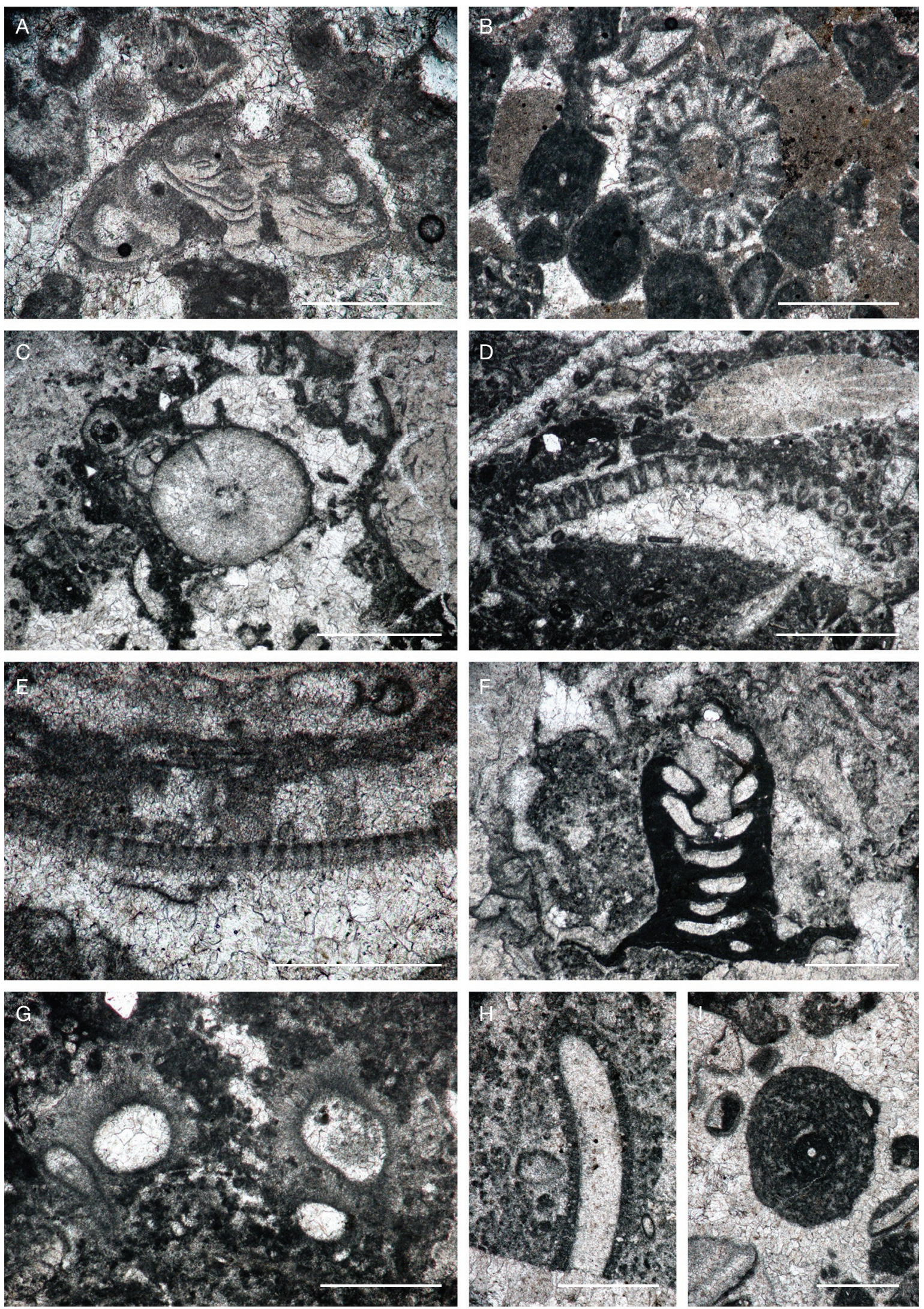

FIG. 3. - Benthic foraminifera, calcareous green algae, terebellid worm tubes and microproblematic organisms from Grădistei Gorges: A, Mohlerinia basiliensis (Mohler, 1938) (sample 15092D); B, Salpingoporella pygmaea (Gümbel) (sample 15092D); C, Nipponophycus ramosus Yabe \& Toyama (sample 15092L); D, Griphoporella sp. (sample 15092H); E, Thaumatoporella parvovesiculifera (Raineri, 1922) (sample 15092H); F, Crescentiella-type encrusting microstructure (Labes atramentosa Eliášová, 1986) (sample 15092I); G, Radiomura cautica Senowbari-Daryan \& Schäfer, 1979 (sample 15092C 1 ); H, Terebella lapilloides Münster, 1833 (sample 15092R); I, Crescentiella morronensis (Crescenti, 1969) (sample 15092W). Scale bars: $0.5 \mathrm{~mm}$. 
TABLE 1. - Description of the main microfacies types (MTF) for the Upper Jurassic carbonate succession from the Grădiștei Gorges.

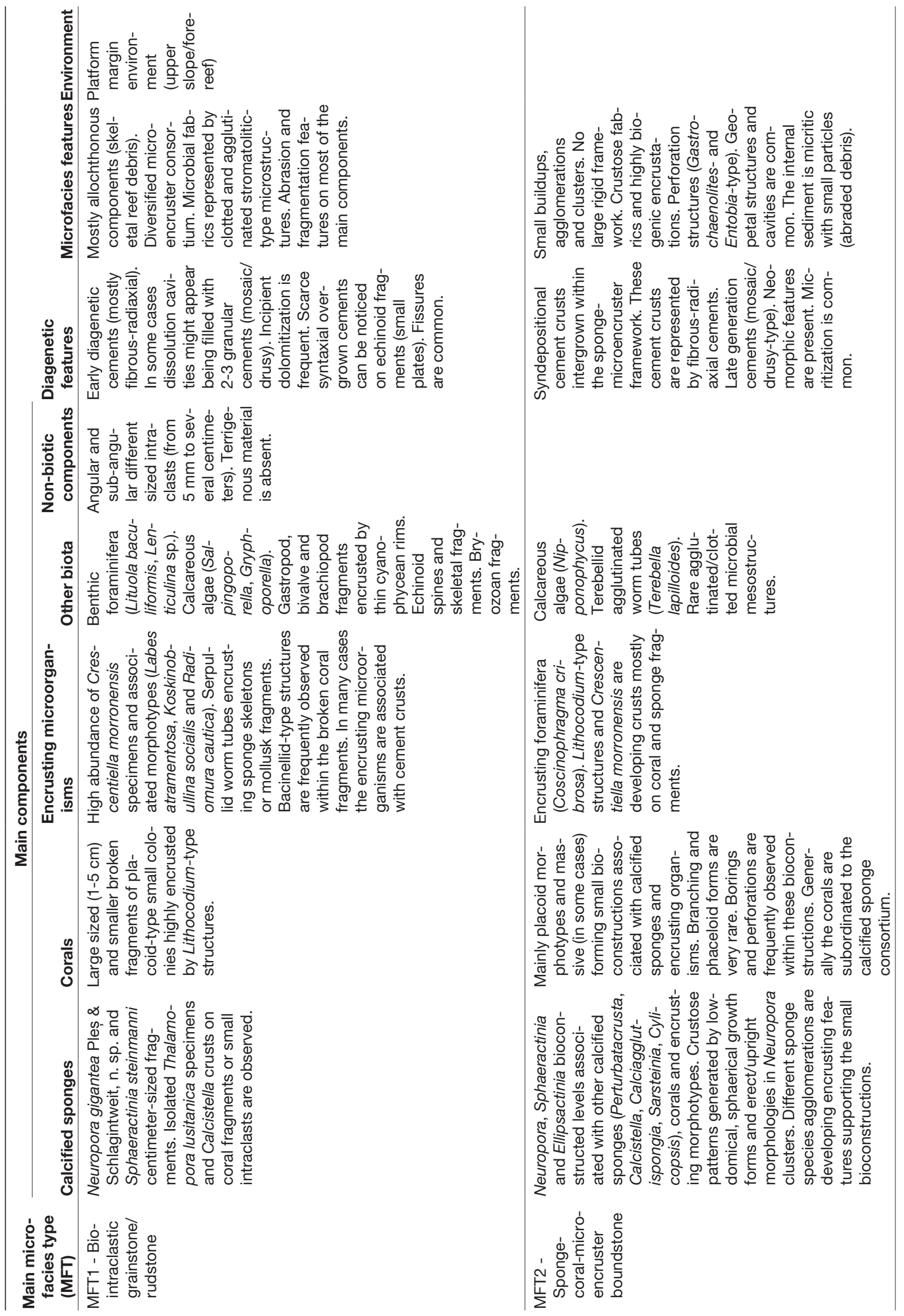



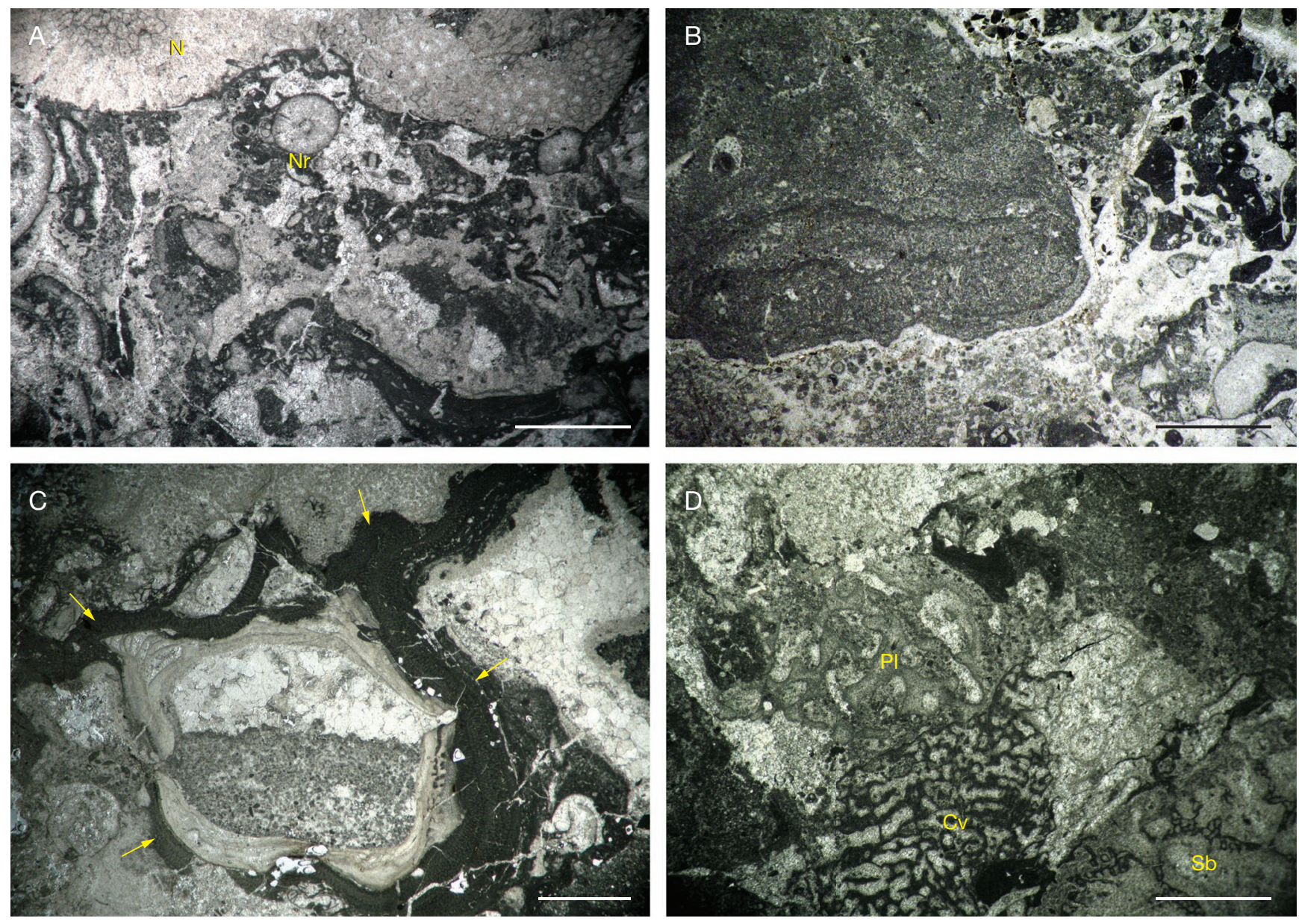

FIG. 4. - Main microfacies types from Grădiștei Gorges: A, sponge-microencruster boundstone (MFT2) with Neuropora gigantea Ples \& Schlagintweit, n. sp. (N), Nipponophycus ramosus Yabe \& Toyama (Nr), Crescentiella morronensis (Crescenti, 1969) and numerous cement crusts (sample 15092C 1 ); B, coarse biointraclastic rudstone (MFT1) with a large microbial mesostructure (agglutinated microbialite) (sample 15092W); C, reef boundstone with cement crusts and encrusting calcified sponges (yellow arrows) (sample 15092G); D, crustose poriferan boundstone with Perturbatacrusta leini Schlagintweit \& Gawlick, 2011 (PI), Cylicopsis verticalis Turnšek, 1968 (Cv) and Sarsteinia babai Schlagintweit \& Gawlick, 2006 emend. (Sb) (sample 15937). Scale bars: 1 mm.

larger branching morphotype which is the most common one. In the studied material, all observed specimens develop tubular (cylindrical) growth patterns or appear as abraded fragments encrusted by Lithocodium-type crusts within the fore-reef carbonates. It is quite possible that some fragments might have originated from branching-type specimens since such forms were frequently reported from Buila-Vânturarița or Piatra Craiului massifs (Pleș et al. 2013: fig. 7g) as close integrating sedimentary zones of the Getic Carbonate Platform. Well preserved branching specimens were also described recently by Krajewski \& Schlagintweit (2018) from Upper Jurassic reefs from the Crimena Peninsula. On the other hand, the proposed "encrusting" forms of Termier et al. (1985) can be explained by the following:

1) In the generic description of Neuropora, Termier et al. (1985) stated that "This genus presents a double behavior: encrusting in the young ontogenetic stages, then starting to be branched". Taking this into account, the "encrusting" $N$. lusitanica forms represent an incipient development stage in the ontogeny of this sponge rather than a general morphostructural feature.
2) As known from the initial growth stages of chaetetids (Kershaw \& West 1991; West 2011) the selective or inconstantly emergence of a growth center (or centers) of tubules represents a key factor in the morphological development of the skeleton. Therefore it can be deduced that more advanced ontogenetic stages of $N$. lusitanica can have a slightly different growth patterns. According to Kershaw (2012) specimens of the same species can develop different growth morphologies if they died before achieving an advanced ontogenetic stage.

3) It is well known that environmental conditions serve as the main controlling element of the growth phases and external morphological variations in many calcified sponges. Considering the present agitated environment, some adult $N$. lusitanica specimens might develop encrusting patterns when found in clusters (agglomerations) with other encrusting sponges such as Sarsteinia babai or Perturbatacrusta leini.

\section{COMMENTS ON THE SYSTEMATIC POSITION}

The genus Neuropora represents even today the subject of numerous debates regarding its systematic placement among the complex hierarchy of the calcified sponges phylogeny. 
In a broad perspective, some Neuropora morphotypes can be compared (in terms of structural organization and external morphology) with other groups of invertebrates (anthozoans, bryozoans) thus the presumption for a bryozoan nature stood for decades (Walter 1969). Moreover, Schlagintweit \& Ebli (1999) observed that $N$. lusitanica might share the same palaeoecological niches with bryozoans and can exhibit a similar "light honey-coloured appearance". The bryozoan origin of Neuropora was placed under a question mark by Hillmer (1971) while studying the Cretaceous bryozoans from western Germany. Soon after, Brood (1971) temporarily assigned this genus to the stromatoporoids. The first irrefutable evidence for a sponge affinity of Neuropora was presented by Kaźmierczak \& Hillmer (1974) based on the discovery of monoaxonoid spicules within the fibrous skeleton of the type species Neuropora pustulosa Roemer, 1839. The observed morphostructural semblances (spicules, basal skeleton and external features-mamelonar microstructures) between $N$. pustulosa and Ceratoporella nicholsoni (Hickson, 1911) encouraged Kaźmierczak \& Hillmer (1974) to place Neuropora in the "Ceratoporellidae" family of the sclerosponge group. Even if a chaetetid feature was recognized by Termier et al. (1985) in the encrusting morphotypes of Neuropora, the authors established the "Neuroporidae" family to comprise this genus. In his substantial work on coralline sponges, Reitner (1992) noticed also a typical chaetetid architecture of $N$. pustulosa basal skeleton with ceratoporellid-type features in some specimens. Even if the overall development of the skeleton points to a chaetetid affinity, Termier et al. (1985) and Reitner (1992) stated that in advanced ontogenetic phases Neuropora specimens are often displaying an immature or partial organization. Following West et al. (2013), the genus Neuropora belongs to an uncertain family of hypercalcified chaetetid-type demosponges.

\section{STRATIGRAPHIC RANGE}

The known stratigraphic distribution of Neuropora lusitanica ranges between the upper Oxfordian (Termier et al. 1985) and the lower Aptian (Pleș et al. 2017) with an acme period during the late Kimmeridgian-Tithonian interval (Schlagintweit \& Ebli 1999; Leinfelder et al. 2005; Schlagintweit \& Gawlick 2008; Pleș et al. 2013).

Neuropora gigantea Pleș \& Schlagintweit, n. sp. (Fig. 5C-E; 6A, B)

urn:Isid:zoobank.org:act:90AF1B11-3DC3-4FFB-BA5E-9C4FCE5D55F6

Derivation OF NAME. - The name of this species comes form the latin word gigas (giant, large) due to the large size of its skeleton.

MATERIAL. - One longitudinally sectioned specimen (holotype, sample 15092A), two transversely sectioned specimens (sample15092B), one bifurcated specimen (sample 15092C1), three transversely sectioned individuals (samples 15092C1 and15092D), one large individual (sample 15092H) and three transversely sectioned specimens (sample 15092L) together with numerous oblique/ transverse sectioned specimens and several fragments (more than thirty specimens).
MEASUREMENTS. - The holotype is $4.3 \mathrm{~cm}$ high, $0.7 \mathrm{~cm}$ in diameter; $0.026-0.028 \mathrm{~mm}$ - the size of the tubule walls. The smallest individual is $3.2 \mathrm{~cm}$ in height and $0.5 \mathrm{~cm}$ in diameter, while the largest individual is $7.2 \mathrm{~cm}$ in height and $1.3 \mathrm{~cm}$ in diameter. Most of the measured specimens have the height of the skeleton between $4-5 \mathrm{~cm}$ with a diameter of $0.6-0.9 \mathrm{~cm}$.

HOLOTYPE. - The longitudinally sectioned specimen from Figure 5E (sample 15092A, repository number 24127).

DEPOSITORY. - The holotype and other used thin-sections are stored at the Museum of Geology-Paleontology (Babeș-Bolyai University) under repository number 24127-24154.

TYPE LOCALITY. — Romania. The Grădiștei Gorges touristic complex (Brașov County).

TYPE LEVEL. - Upper Jurassic (Kimmeridgian-Tithonian) carbonates of the Giuvala Formation (Urdărița Member).

DiAGNOSIS. - Large sized poriferan (more than seven centimeters in height) with a cylindrical erect skeleton (sometimes bifurcated) and a pale yellow color. Both transverse and longitudinal sectioned specimens shows a fibrous pattern of the skeleton microstructure (Fig. 5C). A group of densly packed primary tubules with thin walls is forming a rigid axial zone of the skeleton. In transverse section, it can be observed that some of the main tubules possess small septa developed perpendiculary on tubule wall. Secondary elongated tubules are diverging from these central elements towards the peripheral zones of the skeleton (Fig. 5C, E). They are segmented by very thin tabulae. Some specimens can bear perforation marks. Spicules were not observed so far.

\section{REMARKS}

These large Neuropora specimens are dominating the sponge assemblage from Grădiștei Gorges. They can develop agglomerations or clusters (up to ten specimens) massively encrusted by cyanophyceans and Lithocodium-type crusts. Often they are associated with Sphaeractinia/Ellipsactinia and coral fragments. The assignment of this calcified sponge to the genus Neuropora was made based on the general diagnostic traits highlighted by Termier et al. (1985). Despite the fact that Neuropora gigantea Pleș \& Schlagintweit, n. sp. shares some morpho-structural affinities with $N$. lusitanica (axial tubules from which lateral tabulated tubes are diverging towards the margins of the skeleton), detailed thin-section analisys have evidenced discrepancies between both taxa. As opposed to $N$. lusitanica, transverse sections of Neuropora gigantea Pleș \& Schlagintweit, n. sp. show a much denser packing of the axial tubules. In addition, $N$. gigantea Pleș \& Schlagintweit, n. sp. possesses thinner tubule walls $(0.026-0.028 \mathrm{~mm})$ displaying crude septal projections (Fig. 5D). Moreover the section of these tubes is rather irregular than circular as in N. lusitanica. Regarding the tabulae system within the lateral tubes, Neuropora gigantea Pleș \& Schlagintweit, n. sp. have much larger segments between the tabulae developing a "bamboo"-type appearence in longitudinal sections rather than a "cone-incone" pattern as in $N$. lusitanica (Fig. 5A). Also the distance between the tabulae seems to be constant (as noticed by Termier et al. 1985) in N. lusitanica (see Schlagintweit \& Ebli 1999: pl. 7, figs 10, 11 for comparison) as opposed to Neuropora gigantea Pleș \& Schlagintweit, n. sp. where the distance increases progressively towards the peripheral zone 

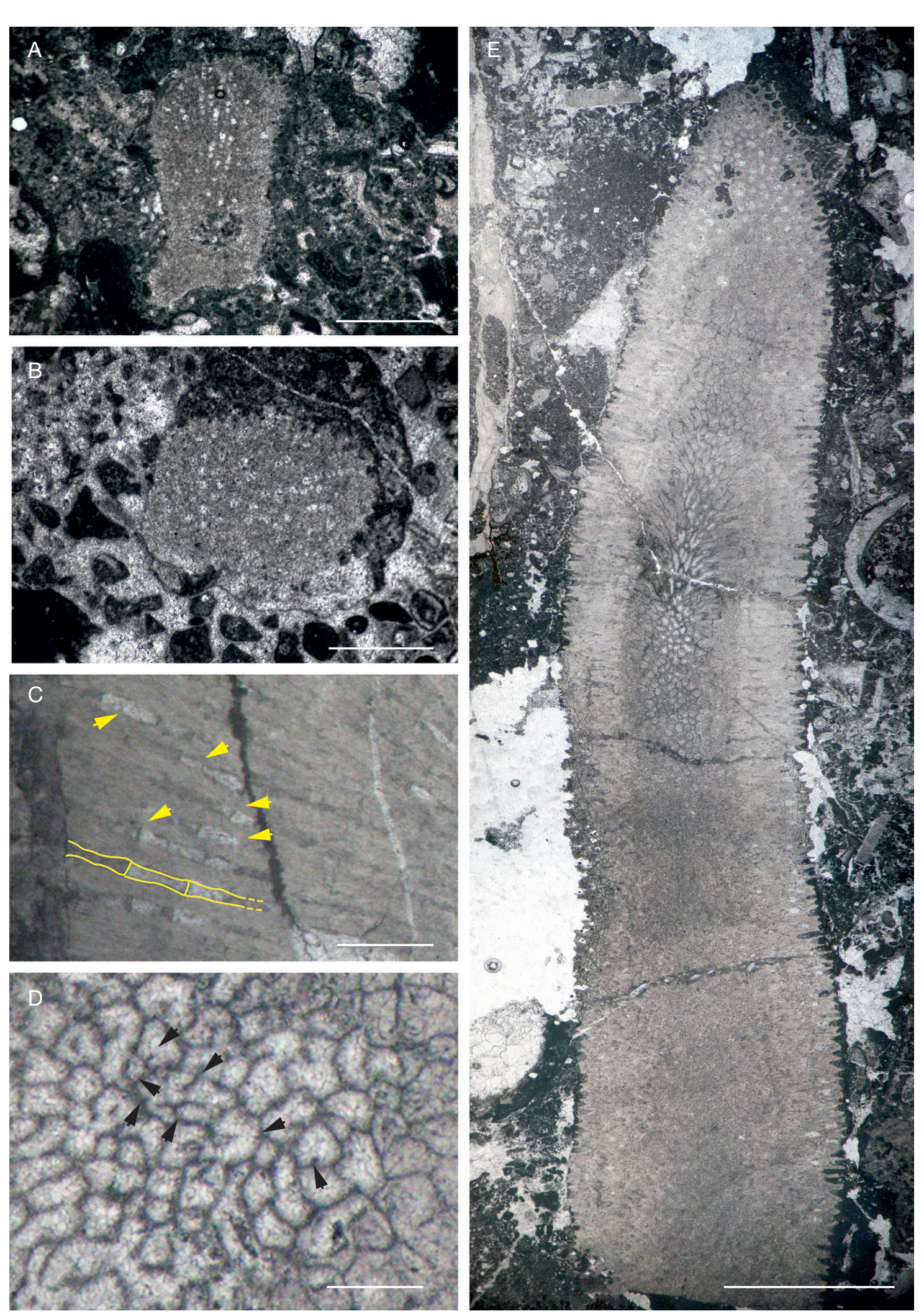

FIG. 5. - A. Neuropora lusitanica Termier, 1985 with a small perforation cavity within the lower part of the skeleton; notice the conically superimposed arrangement of the small tubules (sample 15092L); B, Neuropora lusitanica (sample 15092P); C, Neuropora gigantea Ples \& Schlagintweit, n. sp. Iongitudinally/oblique sectioned specimen; note the elongated tubules segmented by very thin tabulae (yellow arrows) developing a "bamboo"-type appearance; the yellowish fibrous pattern of the skeletal microstructure is also visible (sample $15092 C_{1}$ ); D, cross-sectioned axial zone of Neuropora gigantea Ples \& Schlagintweit, $n$. sp. skeleton showing the closely packed axial tubules with thin septal projections (black arrows) (sample 15092B); E, Neuropora gigantea Ples \& Schlagintweit, n. sp. holotype; note the secondary elongated tubules diverging from the central elements (primary tubes) towards the peripheral zones of the skeleton (sample 15092A). Scale bars: A-C, $1 \mathrm{~mm} ; \mathrm{D}, 0.5 \mathrm{~mm} ; \mathrm{E}, 0.5 \mathrm{~cm}$. 
of the skeleton (Fig. 5C). Field observations have revealed that some of these large sponges have small bulbs or lumpy microstructures on the surface of the skeleton. Astrorhizaetype structures or stellate patterns were not observed. It is possible that Neuropora gigantea Pleș \& Schlagintweit, n. sp. and $N$. lusitanica specimens might possess such structures similar to $N$. pustulosa (West et al. 2013) but due to the abrasion and intense fracturing (generated by the agitated environment) they were not preseverd here. Last but not least the size of Neuropora gigantea Pleș \& Schlagintweit, n. sp. (more than $7 \mathrm{~cm}$ in height and $1.3 \mathrm{~cm}$ in diameter) can represent a distinctive feature in comparison with $N$. lusitanica (average height 1-2 cm; diameter 3-3.5 mm) (Termier et al. 1985).

\section{COMMENTS ON THE SYSTEMATIC POSITION}

Based on the general morphostructural traits of its skeleton, a chaetetid-type bauplan is recognized for Neuropora gigantea Pleș \& Schlagintweit, n. sp. However, the lack of spicules from the analysed specimens makes the assignment to a specific order or family of calcified sponges very difficult.

\section{Genus Sphaeractinia Steinmann, 1878}

Sphaeractinia steinmanni Canavari, 1893 (Figs 6C; 7A-C, E)

Sphaeractinia steinmanni Canavari, 1893: 52, table 5, fig. 4. — Milan 1969: 169, table 12, figs 1, 2.

\section{GENERAL DESCRIPTION}

Large sized colonial calcified sponge (up to $5-6 \mathrm{~cm}$ in diameter) with a spherical/subspherical skeleton ("coenosteum" sensu Milan 1969) and a radial growth pattern. The main morphostructural features of Sphaeractinia steinmanni are represented by a series of superimposed arched micritic lamellae (becoming thinner towards the peripheral zones of the skeleton) connected through numerous short pillars (Figs 6C; 7A, C, E) and a radially developed canal system composed of spar filled tubules (sometimes developing astrorhizae-like structures [Fig. 7C]). The lamellar spaces possess numerous different-sized pores, best visible in the so called "parent lamella" (Fig. 7B) sensu Russo \& Morsilli 2007. The canal system is not regularly developed throughout the skeleton thus the lamellar spaces appear more or less interrupted (in some parts of the skeleton) (Milan 1969). Where bundles of interconnected developed tubules are present (Fig. 6C; 7E), the lamellar spaces are very thin and therfore the skeletal structure appears as possessing a reticulated pattern (“dry-stone wall” sensu Russo \& Morsilli 2007). Monoaxon spicules are rarely observed.

\section{REMARKS}

Sphaeractinia steinmanni represents an abundant species in the Upper Jurassic deposits from Grădiștei Gorges Complex. It may develop clusters (micro-colonies) most commonly with Neuropora, Calcistella and possibly Ellipsactinia. It is worth mentioning the fact that this species was identified due to the very good preservation conditions which allowed insights into the inner- and outer architecture of its skeleton. Both Ellipsactinia and Sphaeractinia share common traits thus the differences between both genera are difficult to observe without well preserved specimens at hands. As opposed to the Ellipsactinia, Sphaeractinia possesses a much higher number of pillars connecting the interlamellar spaces (Fig. 7A) and interconnected tubules (or bundle of tubules) forming in the outermost parts of the skeleton astrorhizae-like canals (Fig. 7C). These are the most important diagnostic traits which can be observed by comparing both taxa (Milan 1969; Russo \& Morsilli 2007). Also, the size of Sphaeractinia is much smaller than Ellipsactinia (Russo \& Morsilli 2007). It is highly possible that Ellipsactinia specimens might be present here. This argument is supported by the fact that some fragments resemble Ellipsactinia microstructure but it is hard to determine if those fragments are part from Ellipsactinia skeletons or fragments of different growth stages of Sphaeractinia. Concerning other Upper Jurassic sphaeractinids, S. steinmanni differs from $S$. diceratina and S. cylindrica by its much better developed canals and through the lack of skeletal extensions (Milan 1969). Last but not least, Russo \& Morsilli (2007) stated that in the so called "Ellipsactinia Limestone" from Upper Jurassic carbonates of Gargano promontory (Italy), Sphaeractinia is much more abundant than Ellipsactinia, as is also the present case in the Getic Carbonate Platform.

\section{COMMENTS ON THE SYSTEMATIC POSITION}

Generally, Sphaeractinia possesses (as most of the sponges described here) a stromatoporoid-type skeletal structure. Based on the main skeletal structure (canal system and radial elements), Sphaeractinia shares similarities with Actinostromina. For that reason Bachmayer \& Flügel (1961) followed by Milan (1969) assigned Sphaeractinia (and also Ellipsactinia) to the order Spheractinoidea, superfamily Actinostromariidae, family Spheractinidae of the calcified demosponges.

\section{STRATIGRAPHIC RANGE}

Upper Jurassic (Kimmeridgian-Tithonian) (Milan 1969; Russo \& Morsilli 2007; Schlagintweit \& Gawlick 2007; Rusciadelli et al. 2011).

\section{Genus Calcistella Reitner, 1991}

\section{Calcistella jachenhausenensis Reitner, 1992}

(Fig. 7D)

Calcistella jachenhausenensis Reitner, 1992: 157, pl. 24, figs 3-6. Pleș et al. 2017: 104, fig. 8c.

\section{GENERAL DESCRIPTION}

Crustose sponge with densly packed aster-type microscleres and a canal system composed mostly of vertical tubules (Fig. 7D) with a light-orange color in normal transmitted light. Probably the most characteristic morpho-structural feature of C. jachenhausenensis is the concentrated agglomeration of tiny 

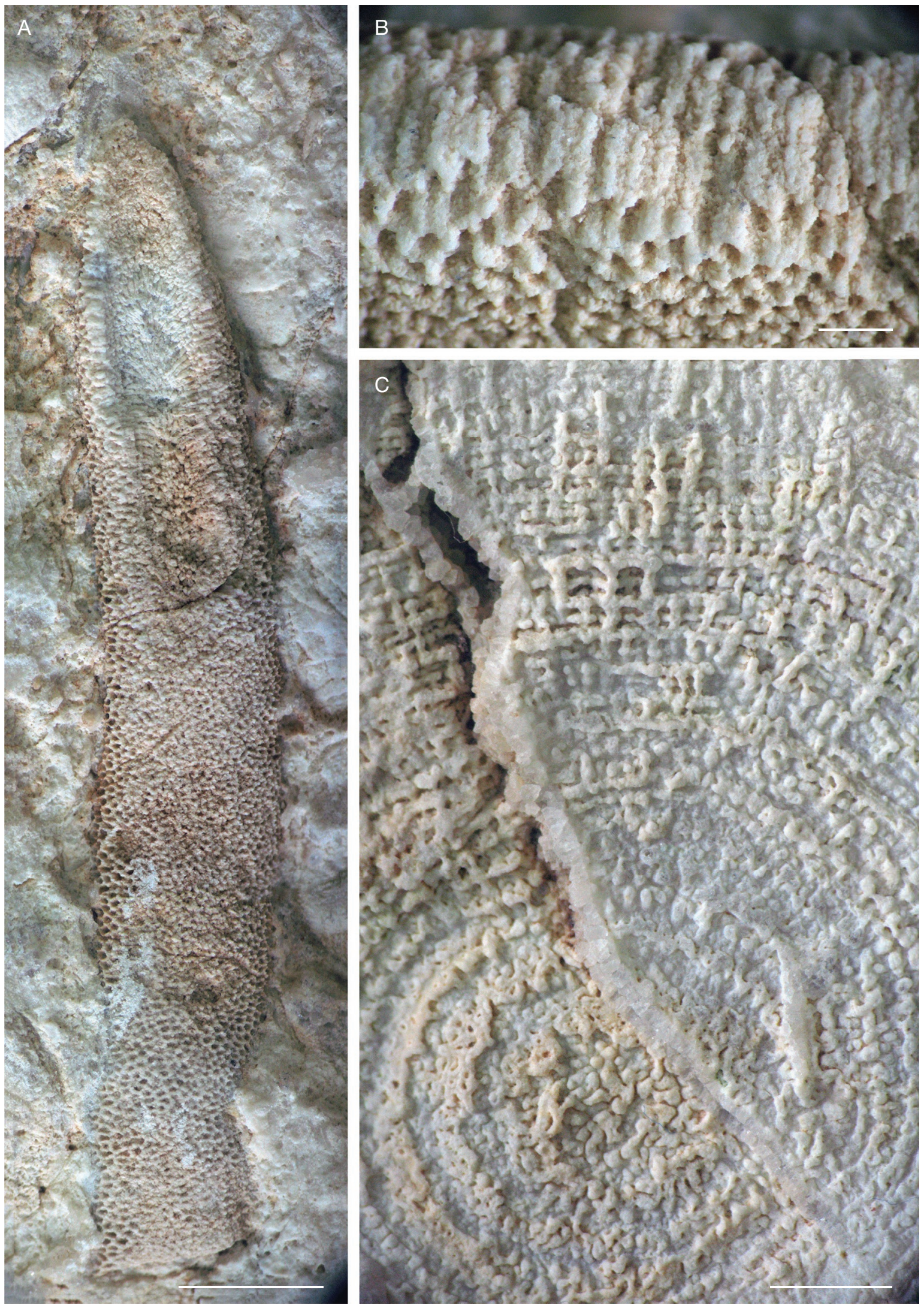

FIG. 6. - Weathering surface of the Grădiștei Gorges carbonates: A, well preserved Neuropora gigantea Pleș \& Schlagintweit, n. sp. specimen showing the external openings of the secondary tubules; B, transverse close-up view of the fibrous microstructure of the secondary elements in Neuropora gigantea Ples \& Schlagintweit, n. sp.; C, Sphaeractinia steinmanni Canavari, 1893 large specimen showing the inter-lamellar spaces pierced by numerous pillars and tubules. Scale bars: A, $1 \mathrm{~cm} ; \mathrm{B}, 1 \mathrm{~mm} ; \mathrm{C}, 0.5 \mathrm{~cm}$. 
spherical (aster-type) microscleres (Reitner 1992; West et al. 2013; Kaya \& Altiner 2015; Pleș et al. 2017). The canal system is developed throughout the sponge skeleton and contains, beside the main vertical tubules, radially-arranged tubules (especially in the upper part) (Reitner 1992). This tubular organization can be regarded as the exhalant/inhalant system of $C$. jachenhausenensis. Tabulae are very rare. Reitner (1992) observed two types of secondary skeletal microstructures: a short-fibred calcite (first calcification phase) and micriticl granular microstructure. A stromatoporid-type organization was regarded by Reitner (1992) and Kaya \& Altiner (2015) for the secondary skeleton of $C$. jachenhausenensis.

\section{REMARKS}

Here, Calcistella jachenhausenensis was identified developing crustose fabrics around coral fragments and Neuropora specimens. Some Calcistella crusts can exceed 7-8 cm in thickness and possess well developed vertical tubules (Fig. 7D) best observed in cross-sections. This tubule system seems to be relatively dense and inter-tubular connections are very rare (Fig. 7D). The typically packed pattern of the spherical scleres (euasters) is visible in all C. jachenhausenensis crusts independently from the section plane. Regarding the mineralogy of the skeleton, Reitner (1992) stated that the original "organo/ collagen matrix" of the primary skeleton was diagenetically replaced by a synvivo fibrous micrite.

\section{COMMENTS ON THE SYSTEMATIC POSITION}

According to Reitner (1992) Calcistella jachenhausenensis possesses a chaetetid-type basal skeleton, feature observed also in C. tabulata from the Albian of Greece (Reitner 1991). Compared to $C$. tabulata Reitner, $C$. jachenhausenensis has a rather crude system of tabulae (or completely absent). In the studied specimens this feature was not encountered. The sclere stacking is also much denser in C. jachenhausenensis. Moreover the tubular system from the holotpye of C. tabulata (Reitner 1992: pl. 24, fig. 1) seems to be more closely-spaced and of larger size than in C. jachenhausenensis. Based on its general traits (especially the euaster-type microscleres) this taxon shares close affinities with the chondrillid-type demosponges. West et al. 2013 included C. jachenhausenensis in the Chondrosida order (Chondrillidae family) of the hypercalcified chaetetid-type demosponge group. Reitner (1992) mentioned the fact that $C$. jachenhausenensis is the first known taxon of this type from the Jurassic.

\section{STRATIGRAPHIC RANGE}

Reitner's (1992) C. jachenhausenensis holotype was found in upper Tithonian carbonates of the Solnhofen Plattenkalk quarry near Jachenhausen locality (Bavaria). Since that, numerous occurrences were noticed in Upper Jurassic (mostly Tithonian) carbonates from many countries of Europe (Austria - Schlagintweit \& Gawlick 2008; Romania - Pleș et al. 2013; Turkey - Kaya \& Altiner 2015; etc.). Beside the Upper Jurassic occurences, Pleș et al., 2017 identified C. jachenhausenensis in lower Aptian deposits from Eastern Carpathians. Sumarizing all, the stratigraphic range of Calcistella jachenhausenensis is Tithonian-lower Aptian with an acme period in ?upper Kimmeridgian-Tithonian.

\author{
Genus Perturbatacrusta \\ Schlagintweit \& Gawlick, 2011 \\ Perturbatacrusta leini \\ Schlagintweit \& Gawlick, 2011
}

(Fig. 7F)

Perturbatacrusta leini Schlagintweit \& Gawlick, 2011: 131, figs 5c, d, 7a-g, 8a-f. — Pleș \& Schlagintweit 2014: 9-11, fig. 4.

\section{GENERAL DESCRIPTION}

Encrusting poriferan with low-domical medium sized skeleton attached mostly on other sponges and corals. The internal architecture of the skeleton is represented by a three-dimensional network of thick horizontal and vertical elements with smooth rounded walls penetrated by a labyrinthic system of interconnected tubules (canal meshwork) (Fig. 7F). According to Schlagintweit \& Gawlick (2011) and Pleș \& Schlagintweit (2014) an axial cavity, spicules and astrorhizae were so far not observed in Perturbatacrusta leini. For a detailed diagnosis see Schlagintweit \& Gawlick (2011) and Pleș \& Schlagintweit (2014).

\section{REMARKS}

Perturbatacrusta leini represents an abundant species within the Upper Jurassic shallow-water encrusting communities of the Tethyan rimmed carbonate platform systems (Schlagintweit \& Gawlick 2008, 2011; Pleș et al. 2013; Kaya \& Altiner 2015). Here, Perturbatacrusta leini was frequently identified as part of encrusting agglomerations associated mostly with $C y l-$ icopsis verticalis, Sarsteinia babai, Calcistella jachenhausenensis, Crescentiella morphotypes and with numerous syndepositional cement crusts (Fig. 4D). Cross- and longitudinally-sectioned individuals revealed that most of the internal tubules are filled with spar cements and, rarely, internal sediment (Fig. 7F). The skeleton has a smooth microcrystalline pattern with a lightgrey colour as similar with other P. leini specimens from the Upper Jurassic carbonates of the Getic Carbonate Platform (Pleș et al. 2013, 2016; Pleș \& Schlagintweit 2014) and Northern Calcareous Alps (Schlagintweit \& Gawlick 2008, 2011).

\section{COMMENTS ON THE SYSTEMATIC POSITION}

Considering its main morphostructural attributes (encrusting fabric, lack of spongocoel, non-spicular skeleton, etc.) and some resemblances with another microencrusters (Radiomura cautica), Perturbatacrusta leini was either unjustifiably interpreted as Radiomura cautica (see the synonymy list in Schlagintweit \& Gawlick 2011), or considered a microencruster of an unknown systematic position. In the original description of Schlagintweit \& Gawlick (2011) the differences between both taxa (P. leini and $R$. cautica) are clearly explained and a possible poriferan nature of $P$. lein $i$ is discussed. The discovery of several well-preserved $P$. leini specimens in the Upper Jurassic carbonates of the central part of the GCP (Buila-Vânturarița Massif) by Pleș \& Schlagintweit (2014: 11, fig. 4 a-f) allowed new insights into the structural architecture of this species. The labyrinthic system of interconnected tubules and the 

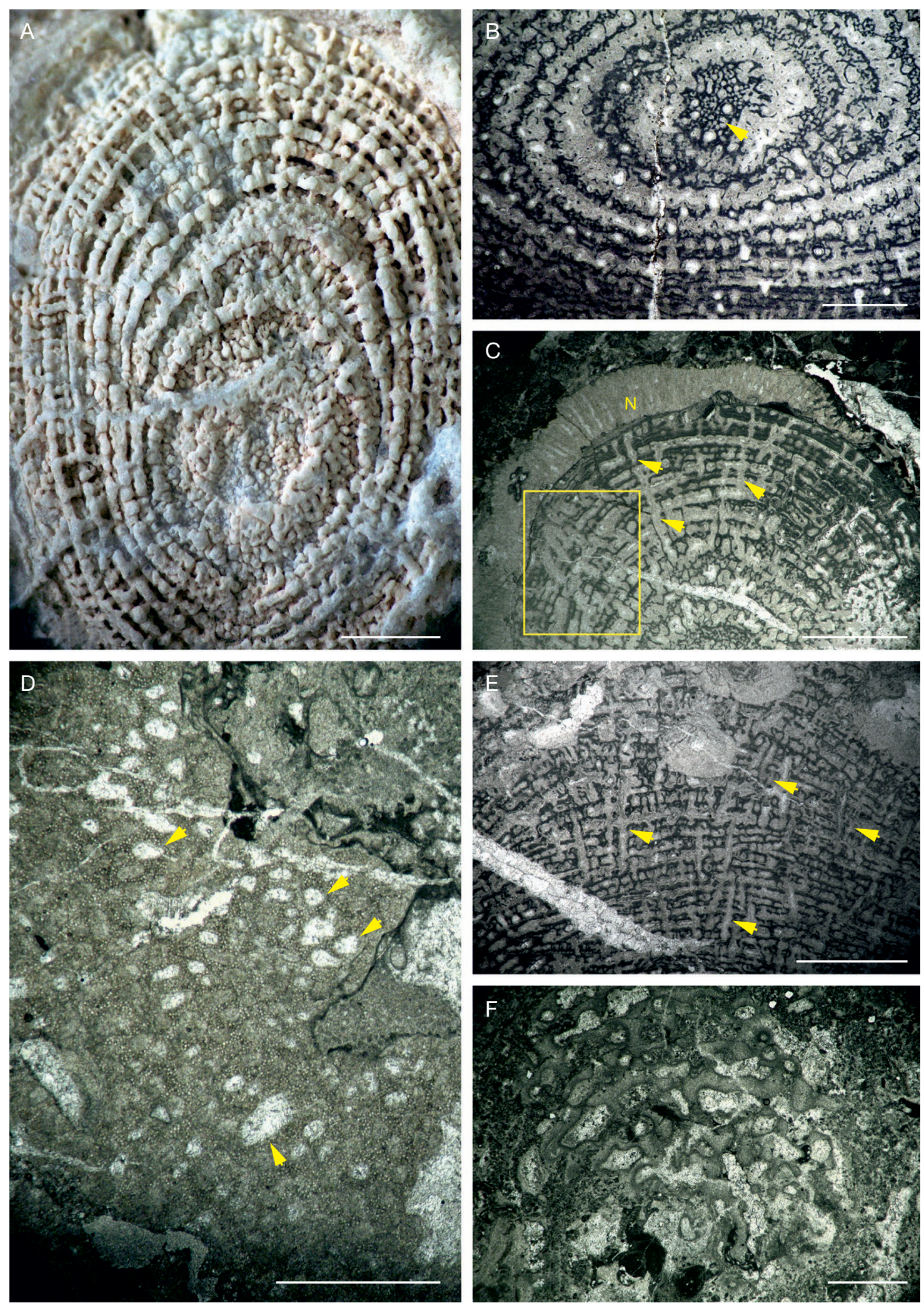

FIG. 7. - A, Sphaeractinia steinmanni Canavari, 1893 in weathering surface; B, cross-sectioned specimen of S. steinmanni showing the parent lamella (yellow arrow) and thick inter-lamellar spaces filled with spar calcite (sample 15092F); C, longitudinal/oblique S. steimanni encrusted by Neuropora Bronn, 1825 (N); numerous large radial tubules can be noticed connecting the inter-lamellar spaces (yellow arrows) or developing astrorhizae-like structures (yellow square) (sample 15092J); D, Calcistella jachenhausenensis Reitner, 1992; notice the densly packed aster-type spherical microscleres and the spar filled vertical tubules (yellow arrows) (sample 15935); E, Sphaeractinia steinmanni with bundles of inter-lamellar tubules (yellow arrows) and its typical reticulated pattern (sample 15092l); F, low-domical encrusting skeleton of Perturbatacrusta leini Schlagintweit \& Gawlick, 2011; notice the smooth microstructure of the skeletal walls and the interconnected system of tubules filled with granular spar calcite (sample 15092S). Scale bars: A, $0.5 \mathrm{~cm}$; B, C, E, $2 \mathrm{~mm} ; \mathrm{D}, 1 \mathrm{~cm} ; \mathrm{F}, 1 \mathrm{~mm}$. 
network of horizontally and vertically developed skeletal elements point to a stromatoporomorph-type development and, respectively, to a poriferan nature of Perturbatacrusta (Ples, \& Schlagintweit 2014). Following these, Perturbatacrusta leini can be regarded as a clacified stromatoporomorph-type sponge rather than a typical microencruster.

\section{STRATIGRAPHIC RANGE}

Kimmeridgian-Berriasian (Schlagintweit \& Gawlick 2011; Pleș \& Schlagintweit 2014; Kaya \& Altiner 2015).

\section{Genus Sarsteinia}

Schlagintweit \& Gawlick, 2006 emend.

\section{Sarsteinia babai}

Schlagintweit \& Gawlick, 2006 emend. (Fig. 8A, B)

Sarsteinia babai Schlagintweit \& Gawlick, 2006: 254-256, pl. 1, figs 1-8. - Kaya \& Altiner 2015: 12, fig. 51-m.

\section{GENERAL DESCRIPTION}

Large sized ( $4.2 \mathrm{~cm}$ in height; $2.8 \mathrm{~cm}$ in diameter) leuconidtype encrusting poriferan with a skeleton pierced by numerous anastomosing tubules forming a complex canal system. Thin section analysis revealed the fact that the canals are filled either by internal sediment or matrix (Fig. 8B) either by druzy- or mosaic-type spar cements (Fig. 8B). According to Schlagintweit \& Gawlick (2006) the canals can possess smooth branches and could represent the exhalant canals of the sponge. The microstructure of the skeleton is characterized by the presence of interconnected dark micritic veins surrounded by a distinct layer of pale-yellow fibrous cement (Fig. 8B). It is possible that some of the micritic veins or fibres may represent septal projections. Spicules were not observed. Following the original description of Schlagintweit \& Gawlick (2006) and Kaya \& Altiner (2015), Sarsteinia babai does not possess a spongocoel and lacks segmentation. The outer surface of the skeleton is defined by the presence of tubercules or ridges.

\section{REMARKS}

Most specimens are found here developing encrusting fabrics together with Calcistella jachenhausenensis, Cylicopsis verticalis or Perturbatacrusta leini. Even so, two cylindrical or "barell"-like specimens (up to $9 \mathrm{~cm}$ ) possess in the central part of the skeleton a large curve-edged cavity (Fig. 8B) that clearely represent the evidence for a spongocoel. Moreover, the outermost parts of the spongocoel are contoured by a micritc band associated with the thin dark fibres which are structuring the sponge skeleton (Fig. 8B yellow arrow). The possible connections of the canal system with the spongocoel are not visible or obturated prior to diagenesis but, considering them as exhalant channels (sensu Schlagintweit \& Gawlick 2006), a relation between these elements should exist. Given the shape, position and the features mentioned above, the observed central cavity in several $S$. babai specimens from Grădiștei Gorges Complex is clearly different than a biotic structure or an abrasional/fragmental feature. As it happens, the specimen illustrated in Fig. 8B displays a large bioerosive structure (perforation) with different observable traits than the existing spongocoel. The identification of a central cavity (spongocoel) in Sarsteinia babai specimens here represents a feature of great diagnostic value. It serve as an additional argument in the emendation of the description made by Schlagintweit \& Gawlick (2006). Apart from this, some of the tubules which form the canal system (?main tubules) are interconnected through various points and appear to spread from the spongocoel to the exterior of the skeleton in oblique/ longitudinal sectioned specimens (Fig. 8B). Frequently, Lithocodium-type superimposed microstructures are observed within the peripheral zones of the skeleton.

\section{COMMENTS ON THE SYSTEMATIC POSITION}

Regarding the systematic position of $S$. babai, following Schlagintweit \& Gawlick (2006) this calcified sponge shares both inozoan (based on the tubular canal system) and stromatoporoid features (considering the skeletal microstructures). Depending on the identified central cavity (spongocoel), the Peronidella-type morphology of inozoans (Rigby \& Senowbari-Daryan 1996) can be used for understanding the morphostructural features and water circulation patterns in Sarsteinia babai. It is highly possible that most of tubules which form the canal system represent inhalant canals, much of the exhalation process being made upward through the spongocoel. Regarding the stromatoporoid affinity of $S$. babai, Schlagintweit \& Gawlick (2006) admit this possibility only in terms of skeletal microstructure. The lack of transverse elements, distinct aquiferous system and other stromatoporoid-type features makes this argument less probable. Considering all, Sarsteinia babai represents an example of calcified inozoanomorph sponge with a stromatoporoidtype skeletal microstructure.

\section{STRATIGRAPHIC RANGE}

Kimmeridgian-?Valanginian (Schlagintweit \& Gawlick 2006; Kaya \& Altiner 2015).

Genus Calciagglutispongia Reitner, 1992

Calciagglutispongia yabei Reitner, 1992

(Fig. 8C, D)

Calciagglutispongia yabei Reitner, 1992: 288, pl. 52, figs 1-4. Leinfelder et al. 2005: 295, fig. 7b.

\section{GENERAL DESCRIPTION}

Medium sized (2.3-2.8 cm in diameter) encrusting poriferan with a thick calcified skeleton characterized by a reticulate network of fibres made of agglutinated small particles (Fig. 8D). According to Reitner (1992) the original mineralogy of the skeleton was spongin. The agglutinated sediment which form 

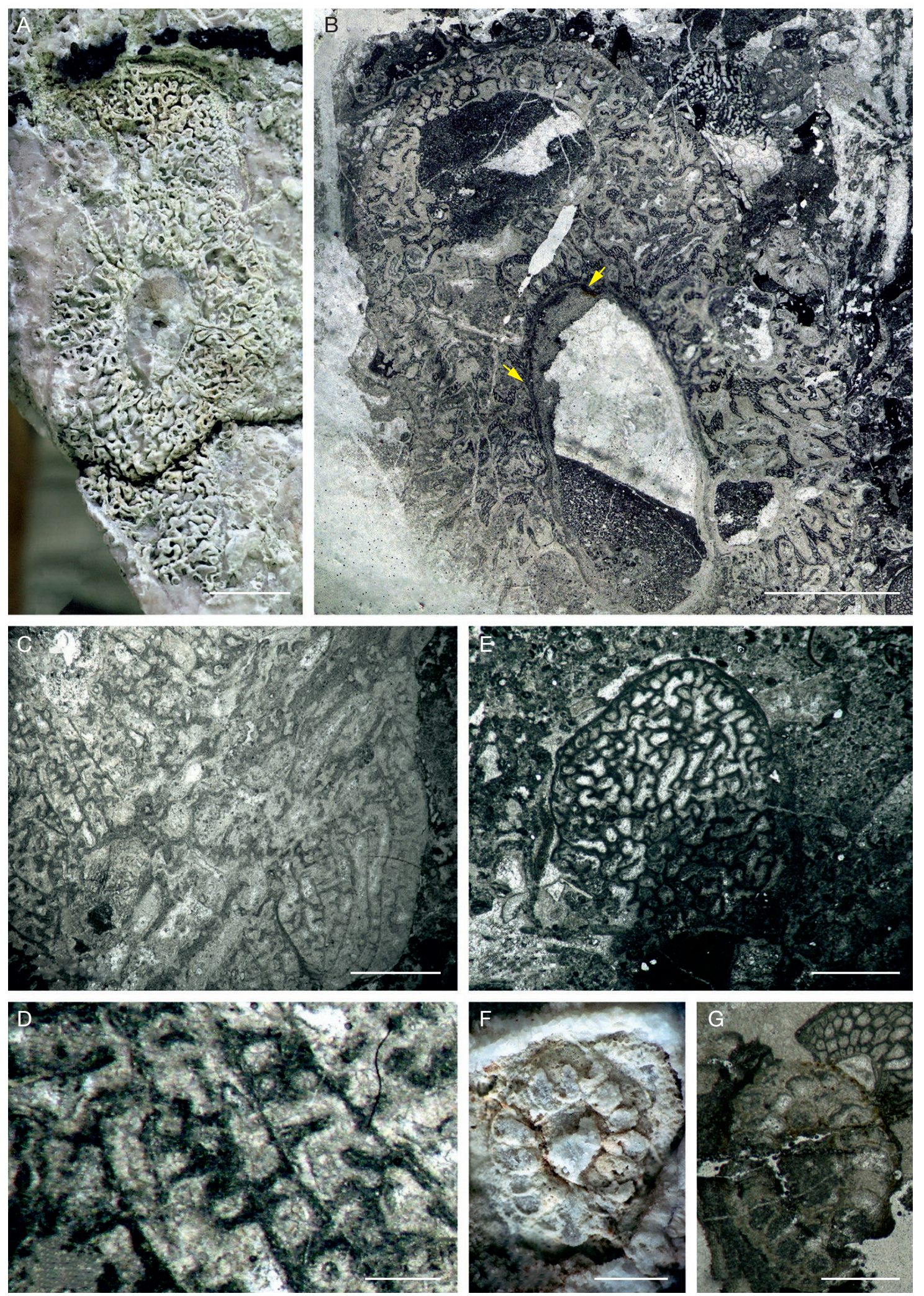

FIG. 8. - A, Sarsteinia babai Schlagintweit \& Gawlick, 2006 emend. in weathering surface; B, longitudinally-oblique section of the S. babai presented in A (sample 15937); the dark micritic veins surrounded by a distinct layer of pale-yellow fibrous cement are noticed throughout the internal structure; in the central part of the skeleton the spongocoel cavity is preserved filled with geopetal sediment; the outermost parts of the spongocoel are contoured by a fine micritic rim (yellow arrows); a perforation cavity is also visible in the upper part of the skeleton; C. Calciagglutispongia yabei Reitner, 1992 showing a system of large central tubules flanked by laterally developed tubes with a superimposed pattern (sample 15092R); D, C. yabei close-up view over the lateral tubes; it can be observed the agglutinated small particles which are forming a network of dark fibers (sample 15092R), E, Cylicopsis verticalis Turnšek, 1968 (sample $15092 \mathrm{~J}$ ); F, Thalamopora Iusitanica Termier, Termier \& Ramalho, 1985 in weathering surface; G, T. Iusitanica longitudinally/oblique sectioned specimen showing the fish-scales imbricated pattern of vesicles arrangement (sample 15092T). Scale bars: A, B, $1 \mathrm{~cm} ; \mathrm{C}, \mathrm{E}, \mathrm{F}, \mathrm{G}, 2 \mathrm{~mm} ; \mathrm{D}, 0.5 \mathrm{~mm}$. 
the inner elements (fibres) is made of fine micritic sediment and grains (Fig. 8B). The canal system shows tube-diameter ranging from 400 to $750 \mu \mathrm{m}$. Spicules were not observed and astrorhizae-type structures are poorly developed.

\section{REMARKS}

Calciagglutispongia yabei specimens here are generally large (up to $5 \mathrm{~cm}$ high) and may develop crustose features. Some longitudinally-oblique sectioned skeletons (Fig. 8C) reveal new insights into the canal system development of this taxon. As illustrated in Figure 8C, a well organized system of large tubules are visible in the central part of the skeleton which is flanked by lateraly developed tubules with a superimposed pattern. The skeletal walls of the central tubules are made also of agglutinated fine micritic sediment being much thicker than the fibre network of the lateral elements. Frequently, Crescentiella morronensis microbodies are found encrusted on Calciagglutispongia yabei skeletons (Fig. 8C).

\section{COMMENTS ON THE SYSTEMATIC POSITION}

Based on the micritic microstructure and its reticulate texture, Calciagglutispongia yabei shares some semblances with the actinostromariid sponges. Reitner (1992) stated that the agglutinated small grains which form the inner-skeletal elements (fibres) point to a keratose affinity of $C$. yabei. Moreover, the calcification model is recorded in numerous poriferans with an organic fiber skeleton. Considering all, Calciagglutispongia yabei can be regarded as a coralline sponge belonging to the Keratosa group (Reitner 1992).

\section{STRATIGRAPHIC RANGE}

Kimmeridgian-Tithonian (Reitner 1992; Leinfelder et al. 2005; Schlagintweit \& Gawlick 2007).

\section{Genus Thalamopora Römer, 1840}

\section{Thalamopora lusitanica Termier,} Termier \& Ramalho, 1985 (Fig. 8F, G)

Thalamopora lusitanica Termier et al., 1985: 214, pl. 9, figs 1-12. Pleș et al. 2015: 53, fig. 5k.

\section{GENERAL DESCRIPTION}

Medium sized chambered calcified sponge $(0.5-0.8 \mathrm{~cm}$ in height; $0.4-0.6 \mathrm{~cm}$ in diameter) with a cylindrical shape and a hollow central cavity (Fig. 8F, G). In early ontogenetic stages the shape of the skeleton is conical and enlarged upward. According to Termier et al. (1985), Thalamopora lusitanica has relatively thick multilayerd walls composed of smooth elliptical elements ("elliptical sclérodermites") in the internal part, a meshwork of tertactine spicules as a middle layer (observed mainly in tangential sectioned specimens) and a microcrystalline fibrous outer layer. The sponge chambers (vesicles) are developed regularly around the central cavity, in longitudinal sections appearing symmetricaly arranged arround the spongocoel. In oblique and sub-axial sections the arrangement of the chambers shows an imbricated pattern (Fig. 8G) described by Termier et al. (1985) as "similar with fish scales" or "glomerate arrangement" sensu SenowbariDaryan \& Rigby (2011). The canal system is characterized by the presence of well organized small tubules. Short tubules are observed within the outer wall of the skeleton opening into the vesicles (Fig. 8G). Inter-chamber connections consist of thin pores best observed in longitudinal sections. Each chamber (vesicle) contains one larger pore (more or less elliptical in shape) which opens into the central cavity. Termier et al. (1985) stated that these elements stored the choanocytes of the sponge. In thin sections, Thalamopora lusitanica can be easily recognized by its chambered (segmented) structure and by its light-orange pored walls.

\section{REMARKS}

As most of the calcified sponges identified here, T. lusitanica occurs in association with microproblematic encrusting morphotypes (Crescentiella or Lithocodium) (Fig. 8G). The vesicules of T. lusitanica are normaly filled with granular spar cement but, in some cases, few may be filled with internal fine sediment prior to abrasion of the skeleton walls (Fig. 8G). It is worth mentioning the fact that this species is not that abundant in comparison with the other poriferan species from the Grădiștei Gorges Complex carbonates. Schlagintweit et al. (2019) described from the Upper Jurassic carbonates from Iran several slightly different Thalamopora specimens (Thalamopora sp.) with lesser chambers in transveres sections in comparison with T. lusitanica.

\section{COMMENTS ON THE SYSTEMATIC POSITION}

The general structure of Thalamopora lusitanica practically follows the development plan of barroisid sponges (Termier et al. 1985; Senowbari-Daryan \& Rigby 2011). The similarities between Thalamopora and Barroisia Munier-Chlamas are related to the skeletal wall design, while the discrepancies should be associated with the presence of elliptical pores and chamber development. As opposed to Barroisia, Thalamopora has a very regular chamber progression and "elliptical sclérodermites" sensu Termier et al. (1985) on the inner parts of the vesicle wall. The second feature is according to Termier et al. (1985) commonly observed in some Permian representatives of the genus Permosphincta Termier \& Termier, 1974, therefore a convergence between Permosphincta-type sponges and sphinctozoans was regarded. In agreement with Senowbari-Daryan \& Rigby (2011) the chambered poriferans are included in the Sphinctozoa group, thus Thalamopora was systematically placed here belonging to the Sphaerocoeliidae order of the Calcispongiae class.

\section{STRATIGRAPHIC RANGE}

Thalamopora lusitanica was found by Termier et al. (1985) in upper Oxfordian deposits from Portugal. Since that, several occurences of this taxon were reported mainly in uppermost Jurassic (Kimmeridgian-Tithonian) intra-Tethyan carbonate platforms from Europe (Bucur \& Săsăran 2005; Leinfelder 
et al. 2005; Săsăran 2006; Schlagintweit \& Gawlick 2008; Pleș et al. 2013; Mircescu et al. 2016). In conclusion the stratigraphic range of T. lusitanica is upper Oxfordian-Tithonian (possibly Berriasian).

\section{DISCUSSION}

\section{TAPHONOMICAL FEATURES}

The development of growth patterns of sponges can serve as important features in understanding some taphonomical processes here. As a rule, the crustose morphologies of most identified sponges (Perturbatacrusta, Calciagglutispongia, Calcistella, Sarsteinia) represent the result of the encrusting potential triggered by the instability of the reef flank sediments and episodic fragmented debris. Associated with numerous microencrusters (Crescentiella, Radiomura, Lithocodium-type microstructures) and early diagenetic cement crusts (mainly fibrous-radiaxial), these sponges formed small bioherms (crustose patches, clusters, agglomerations) and well cemented reef-debris carbonates which have proven to be resistant to subsequent compactation and pressure dissolutions. Given these encrusting morphotypes, skeletal breakage of sponges occurred rarly in such forms, the most susceptible to deterioration being the columnar Neuropora. Even so, many Neuropora specimens are very well preserved (Figs 6A, C; 7A; 8A). Skeleton size can also represent a key factor for the fragmentation resistance as noticed in Sphaeractinia steinmanni large specimens and some Neuropora skeletons. Several diagenetic processes (recrystallization or neomorphic features) can modify the primary microstructure of the sponge skeleton resulting in some diagnostic uncertainties (Reitner 1992; West 2011). This scenario can be partly followed here, since most of the analysed sponges have probably an unaltered skeletal microstructure (as compared with the microstructural diagnostic traits of holotypes and other specimens). West (2011) stated that it is also possible that the main microstructure of some sponges could have been replaced by a diagenetically induced microstructure (prior to recrystalization or micritization processess) which may imitate the original microstructure. This might perhaps explain the smooth microstructure of Perturbatacrusta or the micriticl granular skeletal elements of Calciagglutispongia. As seen in the description chapter, some of the analysed poriferans do not possess spicules (or are very rarely preserved). One way to explain this is via biostratinomic processes. Considering the fact that the spicules of many hyper-calcified sponges are incorporated within the soft tissue of the skeleton (Reitner 1992; West 2011), possibly after death these spicules are either eroded/diagenetically altered or being found sporadically in some parts of the main skeleton. Taking into account that numerous hypercalcified demosponges are known to possess an aspicular skeleton (Reitner 1992; Leinfelder et al. 2005; West 2011; West et al. 2013), it can be deduced that such case can be traced here in some species.

Regardless of the fact that the general preservation of the sponge assemblage is very good, some taphonomical processes are observed to affect the morphostructural features of several species. Bioerosional features (especially borings and perforations) are noticed in Neuropora or Sarsteinia specimens (Fig. 8A) mainly affecting skeletons in advanced ontogenetic stages. Micritization, cyanophycean activity (thin crusts) and replacement cementation can also affect the outermost (peripheral) zones of Neuropora, especially the thin skeletal ellements such as the tabulae system (Fig. 5E). Abrasion might hold back the observation of the astrorhizae-type structures (aquiferous system) on the outer surface of the sponge skeletons but, in some cases, the presence of such structures can be followed within the inner-structure (e.g. Sphaeractinia specimens [Fig. 7C]). Skeletal breakage is present, but with less importance in species identification given the fact that most of the sponges are very well fossilized.

\section{PALAEOECOLOGY AND PALAEOGEOGRAPHIC SETTING}

The palaeoecological significance of Upper Jurassic hypercalcified sponges assemblages represent a subject of great importance in understanding the evolution of reef environments within the intra-Tethyan realm. The available data on Paleozoic stromatoporids (Kershaw 1990; Webby \& Kershaw 2011; Da Silva et al. 2011; Kershaw 2012) and Upper Jurassic northern Tethyan shelves assemblages (Werner et al. 1994; Leinfelder et al. 2005) can be partly used for understanding some of the palaeoecological features exhibited by the present association.

Probably one of the most important response to the environmental settings of the present poriferan assemblage is represented by the morphostructural adaptations resulting in shape/size variations. In respect with the most abundant poriferans, two major trends can be noticed regarding the shape morphologies. First, considering the unstable hard substrate (intraclasts, skeletal debris) of the fore-reef environment, it is obvious that species like Sarsteinia, Calcistella, Perturbatacrusta, Calciagglutispongia (or several Neuropora specimens) should develop mostly crustose, low-domical encrusting growth patterns. Such features are commonly observed on Paleozoic stromatoporoids from high-energy reef settings (Webby \& Kershaw 2011). Second, sphaerical, columnar/cylindrical or branching morphotypes are developed by Sphaeractinia and large specimens of Neuropora gigantea Pleș \& Schlagintweit, n. sp. Even if the abundance of such forms can reflect in most cases low energy conditions (West 2011), a possible explanation for this feature here can be the competition for nutrient supply. Considering the fact that most of the nutrients are divided (or preferentially obtained) by corals and low-domical/encrusting poriferans, a higher elevation (cylindrical/erect form) over the substrate and a bigger size should facilitate additional nutrients (or prioritize the nutrient suply). Also such features can be triggered by fluctuations of the sedimentary input in this agitated environment since intraspecific mophostructural variations (switch from crustose patterns to cylindrical/ columnar) were recorded in some Paleozoic and Mesozoic stromatoporoids (Leinfelder $e$ t al. 2005; Webby \& Kershaw 2011). The same scenario can be applied for large individuals of Sphaeractinia and Ellipsactinia. 
TABLE 2. - Comparison between Intra- and Northern Tethyan calcified sponge occurrences based on Pleș et al. (2013, 2016) for Getic Carbonate Platform (Romania); Schlagintweit $(2011,2012)$ and Schlagintweit \& Gawlick (2007, 2008, 2009, 2011) for Northern Calcareous Alps (Austria); Milan (1969) and Turnšek et al. (1981) for Slovenia and Croatia; Hoffmann et al. (2017) for Stramberk carbonate platform (Czech Republic); Rusciadelli et al. 2011 and Ricci et al. (2018) for Appenines (Italy); Kaya \& Altiner (2015) for Turkey; Termier et al. (1985) for Portugal; Leinfelder et al. (2005) and Reitner (1992) for Spain, Germany and France.

\begin{tabular}{|c|c|c|c|c|c|c|c|c|c|c|}
\hline & \multicolumn{6}{|c|}{ Intra-Tethyan realm } & \multicolumn{4}{|c|}{ Northern Tethyan realm } \\
\hline & Romania & Austria & $\begin{array}{c}\text { Slovenia \& } \\
\text { Croatia }\end{array}$ & $\begin{array}{l}\text { Czech } \\
\text { Republic }\end{array}$ & Italy & Turkey & Portugal & Spain & Germany & France \\
\hline $\begin{array}{l}\text { Neuropora lusitanica } \\
\text { Termier, } 1985\end{array}$ & $\bullet$ & $\bullet$ & - & $\bullet$ & - & $\bullet$ & - & - & $\bullet$ & - \\
\hline $\begin{array}{l}\text { Sphaeractinia steinmanni } \\
\text { Canavari, } 1893\end{array}$ & $\bullet$ & - & $\bullet$ & - & $\bullet$ & - & - & - & - & - \\
\hline Ellipsactinia Steinmann, 1878 & $\bullet$ & $\bullet$ & $\bullet$ & - & $\bullet$ & - & - & - & - & - \\
\hline $\begin{array}{l}\text { Calcistella jachenhausenensis } \\
\text { Reitner, } 1992\end{array}$ & $\bullet$ & $\bullet$ & - & $\bullet$ & - & $\bullet$ & - & - & $\bullet$ & - \\
\hline $\begin{array}{l}\text { Perturbatacrusta leini } \\
\text { Schlagintweit \& } \\
\text { Gawlick, } 2011\end{array}$ & $\bullet$ & $\bullet$ & - & $\bullet$ & - & $\bullet$ & - & - & - & - \\
\hline $\begin{array}{l}\text { Sarsteinia babai Schlagint- } \\
\text { weit \& Gawlick, } 2006 \text { emend. }\end{array}$ & $\bullet$ & $\bullet$ & - & - & - & $\bullet$ & - & - & - & - \\
\hline $\begin{array}{l}\text { Calciagglutispongia yabei } \\
\text { Reitner, } 1992\end{array}$ & $\bullet$ & $\bullet$ & - & - & - & - & - & $\bullet$ & - & - \\
\hline $\begin{array}{l}\text { Thalamopora lusitanica } \\
\text { Termier, Termier \& } \\
\text { Ramalho, } 1985\end{array}$ & $\bullet$ & $\bullet$ & - & - & - & - & $\bullet$ & - & - & - \\
\hline $\begin{array}{l}\text { Cylicopsis verticalis } \\
\text { Turnšek, } 1968\end{array}$ & $\bullet$ & • & $\bullet$ & - & - & - & - & - & - & $\bullet$ \\
\hline
\end{tabular}

Concerning the bathymetric implications of the present sponge assemblage, the identified species were reported mostly from shallow-water fore-reef environments from numerous sites in Europe (Schlagintweit et al. 2005; Schlagintweit \& Gawlick 2008; Pleș et al. 2013; Kaya \& Altiner 2015), as opposed to the northern Tethyan siliceous sponge bioherms which can bloom in much deeper settings. Both sedimentological (abraded skeletal debris, intraclasts, encrusting framework) and palaeontological features (sponges, corals, gastropods, worm tubes, benthic foraminifera, microencrusters) encountered in the Grădiștei Gorges carbonates are sustaining this statement. However, the abundance of Sphaeractinia and Ellipsactinia generally point to a steep angle of the fore-reef flank and, subsequently, to a slightly deeper sedimentary setting (Turnšek et al. 1981; Leinfelder et al. 2005). This is supported also by the fact that the analysed carbonates were developed in the easternmost parts of the Getic Carbonate Platform where a very steep slope existed facing the Sinaia Trough (Patrulius 1976). Furthermore, centimeter-sized Neuropora specimens were identified thriving in much deeper settings within the siliceous sponge facies of Portugal (Werner et al. 1994). Leinfelder et al. (2005) stated that beside Neuropora, no other Upper Jurassic stromatoporoid-type sponge can prosper in the same bathymetric range as the siliceous sponges. Concluding these, a slightly deeper fore-reef environment (several tens of meters) for the Grădiștei Gorges carbonates is assumed.

Given the fact that the present sponge assemblage and the associated palaeontologic content (corals, foraminifera, calcareous green algae) are known to thrive in elevated temperature seas (Leinfelder et al. 2005; Schlagintweit \& Gawlick 2008; Flügel 2010), a warm tropical epicontinental palaeoenvi- ronment it is assumed for the formation of such carbonates. It is known that opposed to corals, stomatoporoids have a much bigger resistance to overheated waters (Kołodziej 2003; Leinfelder et al. 2005). Therefore it can be deduced that the dominance of coral-reefs over stromatoporoids in the northern Tethyan shelves (Spain, Portugal, Germany) can be related to a slightly cooler environment. According to Leinfelder et al. (2005), the observed differences in the stromatoporid distribution throughout the Neotethys point to an increased species abundance in the intra-Tethyan region compared to the adiacent Tethyan zones (where corals or siliceous sponges dominate the reef biota). The authors (Leinfelder et al. 2005) suggested that such features can be related to the poriferan adaptations for much warmer waters, agitated environments and to oligotrophic conditions. This scenario can be followed here since a clearly dominance of calcified sponges abundance versus corals is recorded.

The similarities of the Getic Carbonate Platform (facies associations, biotic content, lithology) with synchronous deposits from Northern Calcareous Alps, Dinarides, Appeninnes (Morsilli \& Bosellini 1997; Schlagintweit et al. 2005; Rusciadelli et al. 2011) point to an equivalent palaeogeographic domain where these isolated carbonate platforms evolved. Based on the existing tectonostratigraphical data and palaeogeographical models (Golonka 2002; Schmid et al. 2008; Gawlick et al. 2009; Missoni \& Gawlick 2011) this large carbonate factory was located in the innermost parts of the Neotethyan ocean (between $20-35^{\circ}$ northern palaeolatitude) bordered by the newly opened Penninic-Piemont ocean (Alpine ocean) to the north, Vardar ocean to the east and open oceanic environment of the Neotethys and African plate (Gondwana) to the southeast-east (Fig. 9). 


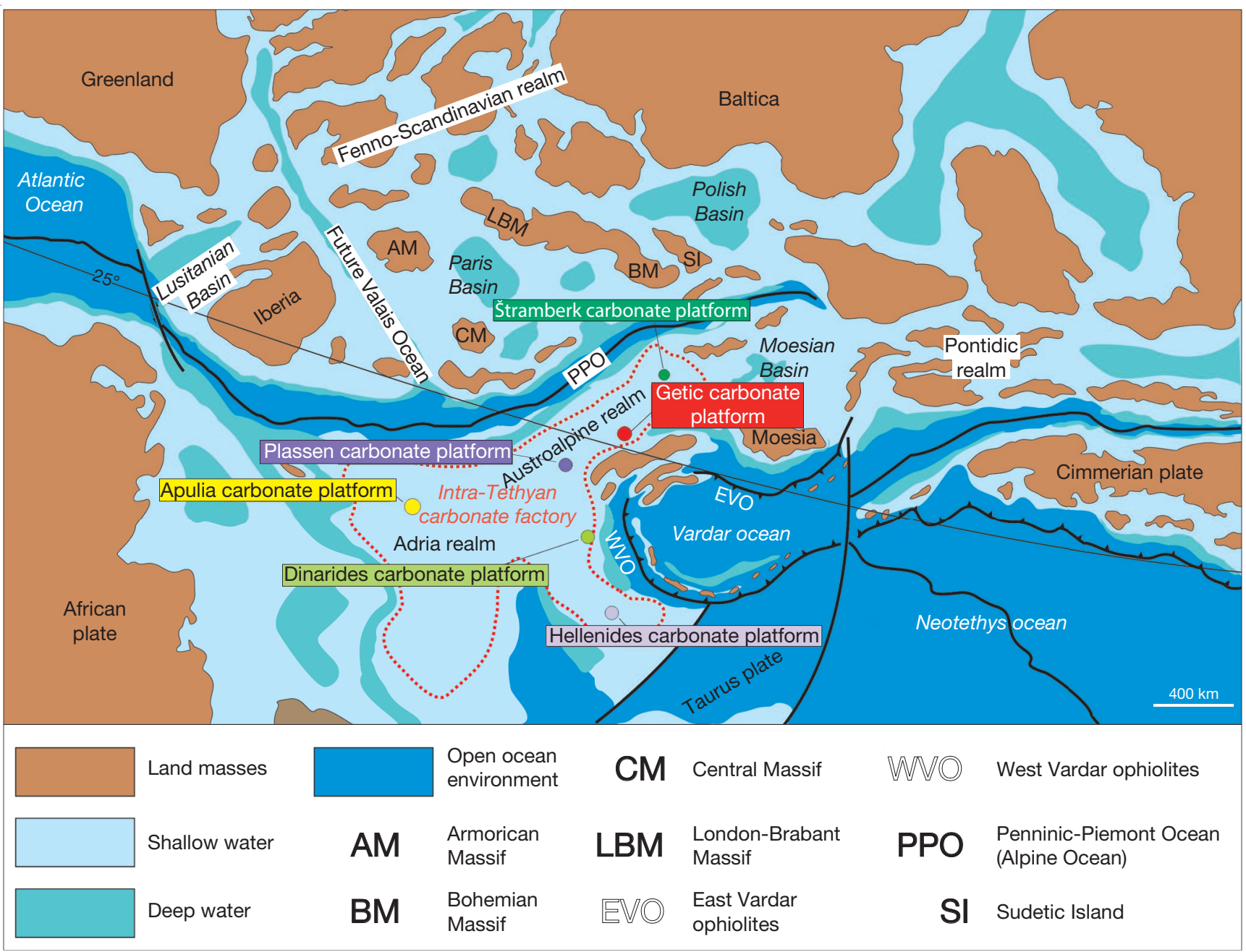

FIG. 9. - Simplified palaeogeographic map for the European Tethyan realm during the Late Jurassic-earliest Cretaceous and the presumed locations of the main intra-Tethyan carbonate platforms based on Paleogeography of Europe Series (Colorado Plateau Geosystems-http://deeptimemaps.com/wp-content/ uploads/2016/05/150_Jur_EurMap).

\section{DISTRIBUTION PATTERNS AND THE INTRA-TETHYAN}

NATURE OF THE SPONGE ASSEMBLAGE

By comparison with the Paleozoic stromatoporoids (Kershaw 1990; Webby \& Kershaw 2011; Da Silva et al. 2011; Kershaw 2012), the distribution patterns of Upper Jurassic calcified sponge assemblages are still poorly documented. Probably one of the most important studies which delt with this subject was made by Leinfelder et al. (2005). The recorded occurrences have revealed that some Upper Jurassic calcified sponge species have a relative broad distribution throughout the Tethyan realm (Table 2). Statistical analysis made by Leinfelder $e t$ al. (2005) on numerous poriferan species from northern, southern and intra-Tethyan shelves highlighted the existence of typical sponge associations for these Tethyan domains with respect to the differences between the palaeoecological and palaeoenvironmental settings.

As implied by the microfacies traits, associated biota and the recorded occurences (Table 2), the present sponge species represent a typical intra-Tethyan assemblage. The poriferan response to the palaeoecological conditions (climate, water temperature, bathymetry, nutrients) and palaeoenviron- ments resulted in preferential adaptations to a specific region (Table 2). This might explain the occurences of Ellipsactinia and Sphaeractinia only in the tropical shallow-waters carbonates of the intra-Tethyan shelves. Moreover, due to their specific morphostructural features (mostly encrusting skeletons), Perturbatacrusta leini and Sarsteinia babai thrived only in the intra-Tethyan small reefs of numerous isolated carbonate platforms (Table 2). As mentioned previously, some sponges have a higher adaptability rate to different ecological conditions, therefore Neuropora lusitanica might dwell also in slightly cooler, deeper environments of the northern Tethyan shelves (Table 2). Even if $N$. lusitanica represents a cosmopolitan species throughout the Tethys, most of its occurences are from coral-sponge-microencruster buildups of the intra-Tethyan carbonate platforms (Schlagintweit \& Gawlick 2008; Pleș et al. 2013, 2015). The same argument can be applied also for Calcistella, Thalamopora and Cylicopsis since very rare examples are recorded from Northern Tethys by comparison with intra-Tethyan abundance (Table 2). Other differences between Northern and intra-Tethyan calcified sponge assemblages can be found in Leinfelder et al. (2005). 

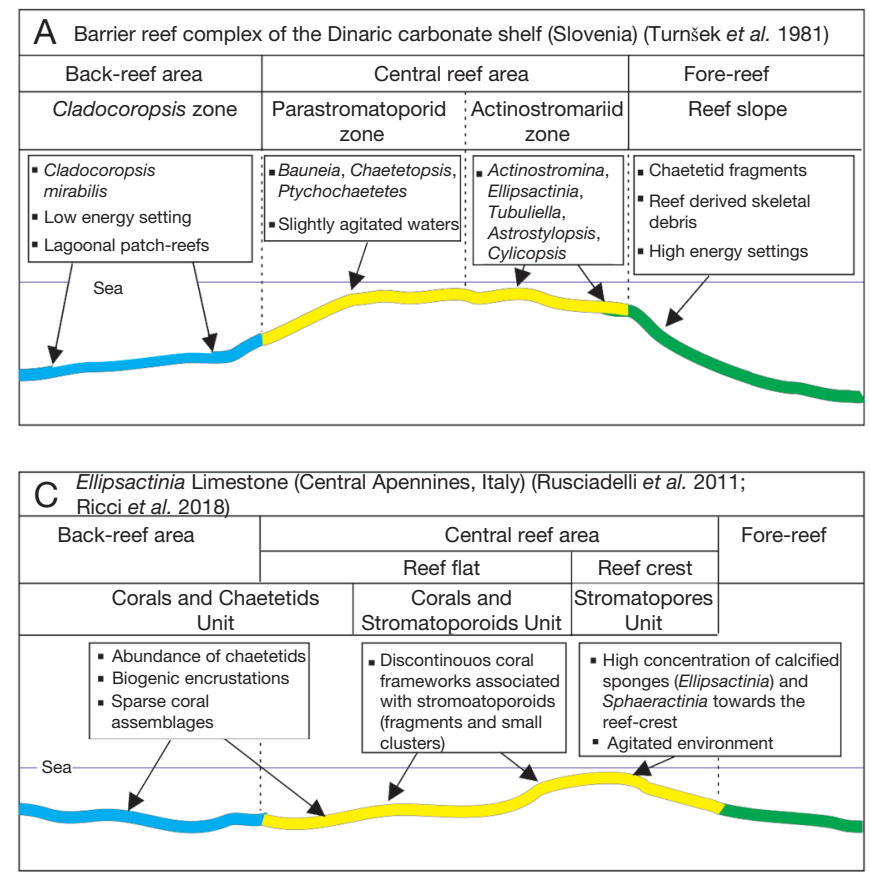
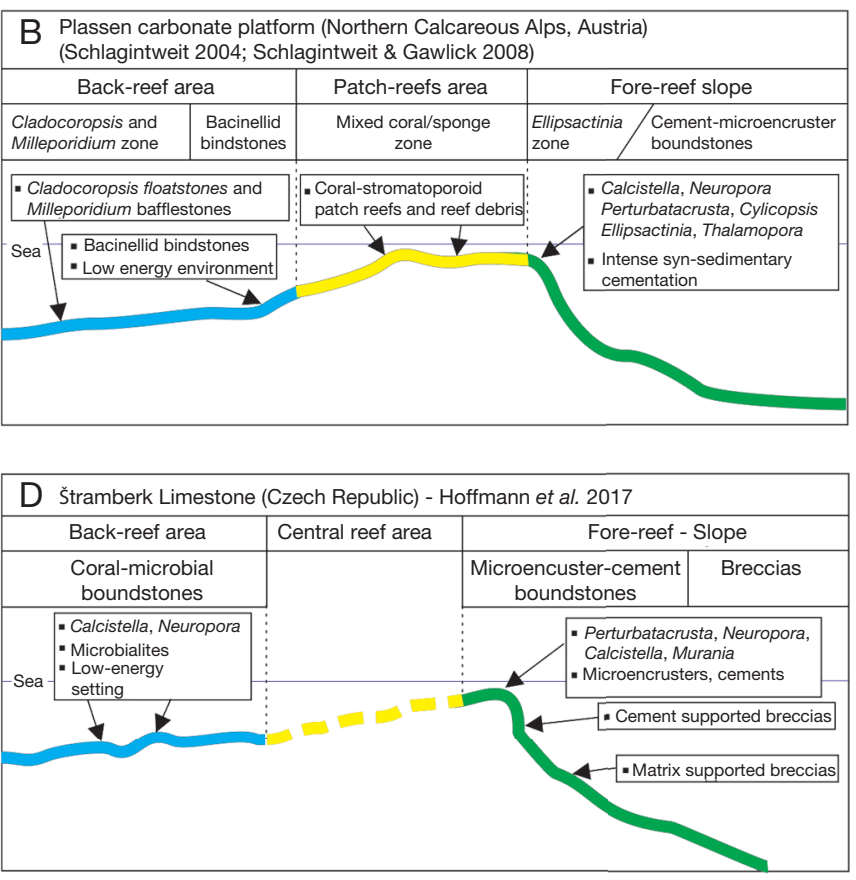

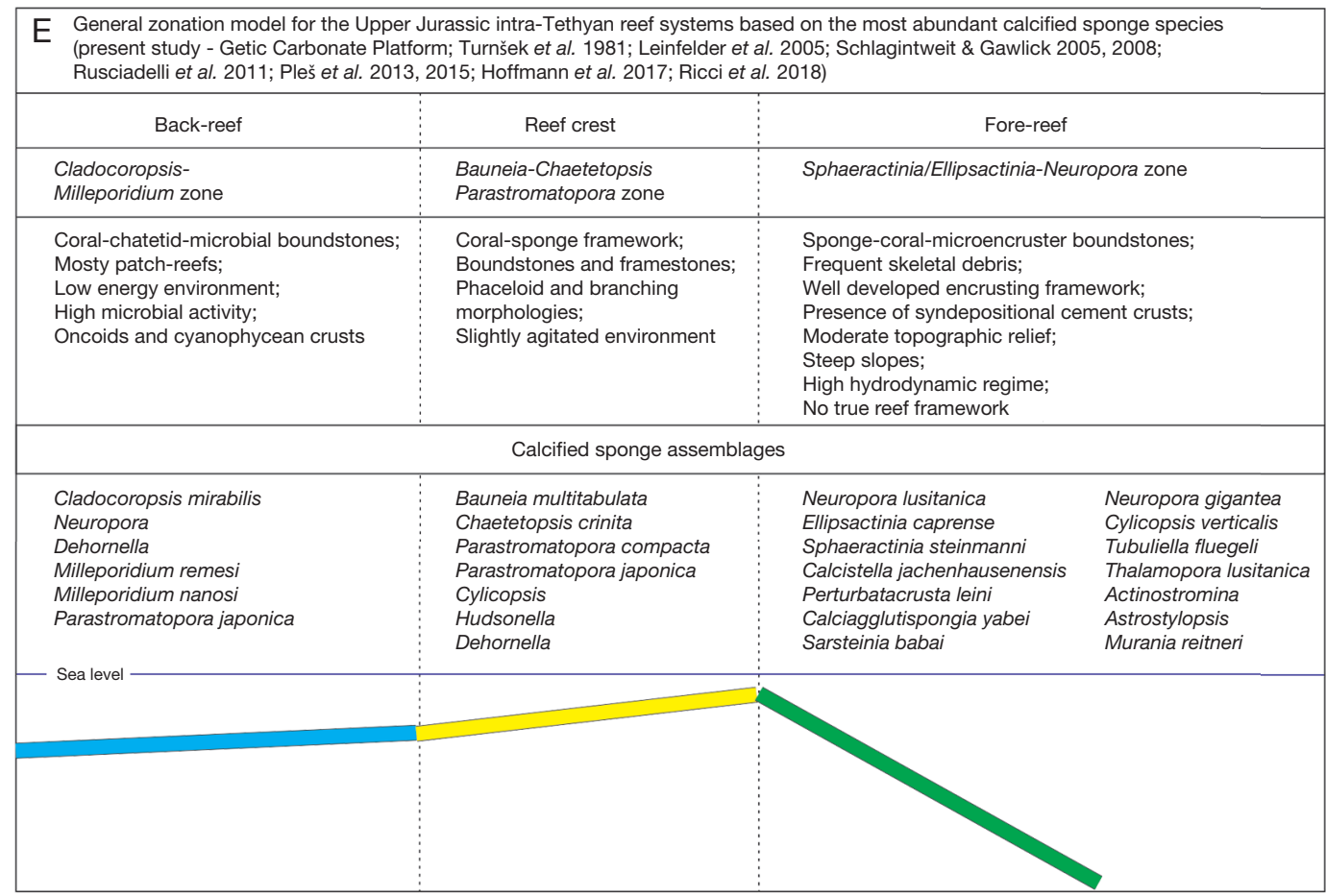

FIG. 10. - General reef zonation modes for the Upper Jurassic intra-Tethyan carbonate platforms based on calcified sponge assemblages.

\section{INSIGHTS INTO REEF ZONATION}

Studies regarding the reef environments of the intra-Tethyan isolated carbonate platforms (Turnšek et al. 1981; Schlagintweit \& Gawlick 2008; Rusciadelli et al. 2011; Hoffmann et al. 2017) have proven that the biotic distribution towards the reef profile is strongly influenced by the environmental conditions generated by adjacent facies zones. Therefore, the calcified sponge species are not randomly distributed throughout the whole reef profile as recorded here or in Upper Jurassic carbonates from
Dinarides (Fig. 10A), central Appenines (Fig. 10C) and Northern Calcareous Alps (Fig. 10B). For example, poriferans like Cladocoropsis or Milleporidium are known to prefer less agitated environments from back-reef areas (Fig. 10A-C). Bauneia, Parastromatopora and Chaetetopsis are frequently reported from the reef flat while high concentrations of Ellipsactinial Sphaeractinia are always indicators for an agitated environment towards the reef flank (fore-reef) (Fig. 10A-C). Based on these and other features discussed previously, the calcified sponge assemblage 
from Grădiștei Gorges is characterizing by all traits a fore-reef environment. It is worth mentioning that Thalamopora lusitanica has a much wider distribution throughout the facies belts (e.g. back-reef and reef flat in the Plassen Carbonate Platform and Ernstbrunn Limestone) (Schlagintweit et al. 2019). The concentration of corals in the adjacent zones (reef flat and back-reef) and possibly the adaptation of Sphaeractinia, Ellipsactinia and Neuropora to oligotrophic conditions, may be one of the answers why these sponges bloom in the fore-reef environment. Even if most of the known reef systems of the intra-Tethyan realm share many similarities (palaeontological content, facies traits, etc.), some discrepancies exist mainly regarding the reef profile (lateral extension, topography, slope inclination) (Fig. 10A-D). Consequently, a general reef zonation model is in a countinous change since new data emerges from recent studies on this topic. Taking these into account a general zonation model for the intra-Tethyan reef systems is proposed here (Fig. 10E) based on the following features: 1) present calcified sponge assemblage, associated biota and facies traits; 2) newest data on other reef carbonates of the Getic Carbonate Platform (Pleș et al. 2013, 2016, 2019); 3) classical reef zonation models (Turnšek et al. 1981; Morsilli \& Bosellini 1997; Rusciadelli et al. 2011); and 4) the avalaible data on the most documented Upper Jurassic intra-Tethyan reefs in Europe (Fig. 10E).

\section{CONCLUSIONS}

An exceptionally preserved calcified sponge association is described from the easternmost part of the Getic Carbonate Platform, Southern Carpathians of Romania. It allows new observations into the internal structure and growth patterns of the main poriferan species in order to decipher the biostratinomical, taphonomical and palaeoecological conditions which influenced the genesis of mixed sponge-coral-microencruster build-ups. Thin section analysis permitted a three-dimensional perspective over the skeletal inner-architecture of all sponge species and, consequently the discovery of new diagnostic features in some species (Sarsteinia babai, Sphaeractinia steinmanni). Moreover, several species are described here for the first time from the Upper Jurassic carbonates of the Southern Carpathians (Calciagglutispongia yabei, Sarsteinia babai, Sphaeractinia steinmanni) including an interesting large Neuropora species (Neuropora gigantea Pleș \& Schlagintweit, n. sp.).

Microfacies analysis provided valuable clues in understanding the depositional palaeoenvironment. By their traits (main components, morphostructural features, diagenetic record) the identified main facies associations (sponge-coral-microencruster boundstones and bio-intraclastic grainstones) point to an agitated reef-flank (fore-reef) depositional palaeoenvironment of a warm tropical epicontinental sea. The instability of the reef flank sediments and episodic fragmented debris led to the development of encrusting morphologies in most sponges (Perturbatacrusta, Calciagglutispongia, Calcistella, Sarsteinia). The abundance of Sphaeractinia, Ellipsactinia and Neuropora generally point to a steep angle of the reef slope and, subsequently, to a slightly deeper sedimentary setting (several tens of meters).
The observed growth patterns of the most abundant calcified sponges show both low-domical encrusting morphologies and spherical or cylindrical shapes. Considering the unstable hard substrate of the fore-reef environment, species like Sarsteinia, Calcistella, Perturbatacrusta, Calciagglutispongia (or several Neuropora specimens) should develop mostly crustose features. The cylindrical or spherical morphotypes (Neuropora and Sphaeractinia) are regarded as a result of the sedimentary input fluctuations in this agitated environment or as structural adaptations triggered by the competition for nutrients. The dominance of calcified sponges versus corals here can be explained by the poriferan adaptations for much warmer waters and agitated environments with lower nutrient input.

The existing palaeoecological and palaeoenvironmental conditions generated preferential adaptations of the sponge species to a specific Tethyan domain and also different distribution patterns towards the reef profile. Therefore, the described calcified sponge assemblage can be used as a supplementary proxy for understanding palaeoecological traits, and consequently, for establishing a general zonation model for the sponge-coralmicroencruster dominated reefs. Corroborating the present material with the existing data on similar carbonates, three poriferan zones are proposed: Cladocoropsis-Milleporidium zone (back-reef area); Bauneia-Chaetetopsis-Parastromatopora zone (central reef area) and SphaeractinialEllipsactinia-Neuropora zone for the fore-reef area. Despite the fact that this model cannot integrate each peculiarity of such Upper Jurassic reef carbonates, it presents the key features in recognizing facies zones based on biotic distribution and the intra-Tethyan character of the analyzed carbonates.

Even if the palaeogeographic picture of the intra-Tethyan realm during the Late Jurassic was characterized mainly by an extensional tectonic regime, this territory provided optimal conditions for the development of relatively small spongecoral-microencruster build-ups on the marginal zones of the existing isolated carbonate platforms. The overall analysis of the calcified sponge assemblage provided valuable information in understanding why these peculiar reefs strongly influenced the carbonate production throughout this realm. In the absence of a true reef framework (e.g. northern Tethyan reefs) the calcified sponges developed typical morphologies, new palaeoenvironmental adaptations and associations with other biotic groups. These features also triggered competitive behavior among these organisms which has generated abundance events and, consequently, a substantial improvement of the bioconstructing potential. Concluding all, this might be one of the answers why a thick succession of uppermost Jurassic bioconstructed/reef debris limestones is recorded in numerous intra-Tethyan carbonates of Europe (Austria, Italy, Romania, etc.).

\section{Acknowledgements}

The authors kindly appreciate the suggestions of Dr Francisco Sánchez-Beristain (UNAM, Mexico). We also thank the second reviewer, Dr Viviana Frisone (Museo "G. Zannato", Montecchio Maggiore, Italy) for the careful reading of the 
manuscript and for the useful recommendations that have improved the quality of the present paper. G.P. likes to thank the phD student Alin Oprișa for preparing the thin-sections used in this study.

\section{Authors contribution statement}

G.P. and F.S. conceived this study, made the systematic paleontology part, discussed the taphonomical features and established the new sponge species Neuropora gigantea Pleș \& Schlagintweit, n. sp. I.L., I.B. and E.S. contributed to the age constraints, microfacies analyses and paleoenvironment interpretations. M.G. design the figures and performed together with G.P. field work campaigns. All authors discussed the results and contributed to the final version of the manuscript.

\section{REFERENCES}

Atasoy S. G., Altiner D. \& OKay A. 2018. - Reconstruction of a Late Jurassic - Early Cretaceous carbonate platform margin with composite biostratigraphy and microfacies analysis (western Sakarya Zone, Turkey): Paleogeographic and tectonic implications. Cretaceous Research 92: 66-93. https://doi.org/10.1016/j. cretres.2018.07.009

BACHMAYer F. \& FlÜgel E. 1961. - Die Hydrozoen aus dem Oberjura von Ernstbrunn (Niederöstrreich) und Stramberg (ČSR). Paleontographica A 116: 122-141.

BECCARO P. \& LAZĂR I. 2007. - Oxfordian and Callovian radiolarians from the Bucegi Massif and Piatra Craiului Mountains (Southern Carpathians,Romania). Geologica Carpathica 58: 305-320.

Brood K. 1971. - The systematic position of Neuropora, Neuroporella and Spinopora. Acta Universitatis Stockholmiensis 23: 65-71.

BUCUR I. I. 1978. - Microfaciesurile calcarelor albe din partea nordică a Masivului Piatra Craiului. Considerații biostratigrafice. Dări de seamă ale ședințelor - Institutul de Geologie și Geofizică 64: 89-105.

BUCUR I. I. 1999. - Stratigraphic significance of some skeletal algae (Dasycladales, Caulerpales) of the Phanerozoic, in FARINACCI A. \& LORD A. R. (eds), Depositional Episodes and Bioevents. Palaeopelagos Special Pubublication 2: 53-104.

BUCUR I. I. \& SĂSĂRAN E. 2005. - Micropaleontological assemblages from the Upper Jurassic-Lower Cretaceous deposits of Trascău Mountains and their biostratigraphic significance. Acta Palaeontologica Romaniae 5: 27-38.

Bucur I. I., Săsăran E., LaZăr I., Dragastan O. N. \& Popa M. E. 2011. - Mesozoic deposits of the Dâmbovicioara couloir, in BUCUR I. I. \& SĂSĂRAN E. (eds), Calcareous algae from Romanian Carpathians, Field Trip Guide Book of $10^{\text {th }}$ International Symposium on Fossil Algae. Presa Universitară Clujeană, Cluj-Napoca: 23-30.

CANAVARI M. 1893. — Idrozoi titoniani della regione Mediterranea alla familia Ellipsactinidae. Memorie del Regio Comitato Geologico d'Italia 4: 155-209.

Ciborowski T. \& Kołodziej B. 2001. - Tithonian-Berriasian calpionellids from the Štramberk-type limestones, Polish Flysch Carpathians. Geologica Carpathica 52: 343-348.

Da Silva A. C., Kershaw S. \& Boulvain F. 2011. - Stromatoporoid palaeoecology in the Frasnian (Upper Devonian) Belgian platform, and its applications in interpretation of carbonate platform environments. Palaeontology 54: 883-905. https://doi. org/10.1111/j.1475-4983.2011.01037.x

Dimitrescu R., PAtrulius D. \& POPESCU I. 1971. — Geological Map of Romania. Sheet 110c. Institutul de Geologie și Geofizică. Dimitrescu R., Popescu I. \& SCHUSTER C. A. 1974. - Geological Map of Romania. Sheet 110a. Institutul de Geologie și Geofizică.
Dragastan O. N. 2010. — Platforma Carbonatică Getică. Stratigrafia Jurasicului și Cretacicului inferior, reconstituiri paleogeografice, provincii și biodiversitate. Editura Universității București, București, 621p. (in Romanian).

DUNHAM R. J. 1962. - Classification of sedimentary rocks according to depositional structure, in HAM W. E. (ed), Classification of carbonate rocks. American Association of Petroleum Geologists Memoirs 1: 108-121.

Embry A. F. \& KLOVAN J. E. 1971. — Late Devonian reef tract on northwestern Banks Island. Bulletin of Canadian Petroleum Geology 19: 730-781. https://doi.org/10.35767/gscpgbull.19.4.730

FLÜGEL E. 2010. - Microfacies of Carbonate Rocks. Analysis Interpretation and Application. Second Edition, Springer, Berlin Heidelberg, 929 p.

Gawlick H.-J., Missoni S., Schlagintweit F., Suzuki H., Frisch W., Krystyn L., BlaU J. \& Lein R. 2009. — Jurassic Tectonostratigraphy of the Austroalpine domain. Journal of Alpine Geology 50: 1-152.

GolonKA J. 2002. - Plate-tectonic maps of the Phanerozoic, in Kiessling W., Flügel E. \& Golonka J. (eds), Phanerozoic reef patterns. SEPM Special Publication 72: 21-76. https://doi. org/10.2110/pec.02.72.0021

GrădinarU M., LAZĂR I., BUCUR I. I., GRĂdinARU E., SĂSĂRAN E., DUCEA M. \& ANDRĂȘANU A. 2016. - The Valanginian history of the eastern part of the Getic Carbonate Platform (Southern Carpathians, Romania): Evidence for emergence and drowning of the platform. Cretaceous Research 66: 11-42. https://doi. org/10.1016/j.cretres.2016.04.012

GRANIER B. \& DELOFFrE R. 1993. - Inventaire critique des algues dasycladales fossiles. II Partie-Les algues dasycladales du Jurassique et du Crétacé. Revue de Paléobiologie 12: 19-65.

Hillmer G. 1971. - Bryozoen (Cyclostomata) aus dem UnterHauterive von Nord-westdeutschland. Mitteilungen aus dem Geologisch-Paläontologischen. Institut der Universität Hamburg 40: 5-106.

Hoffmann M., KoŁodziej B. \& SKUPIEN P. 2017. — Microencrustermicrobial framework and synsedimentary cements in the Stramberk Limestone (Carpathians, Czech Republic): Insights into reef zonation. Annales Societatis Geologorum Poloniae 87: 325-347.

IVAnova D., KoŁodziej B., Koleva-ReKalova E. \& Roniewicz E. 2008. - Oxfordian to Valanginian paleoenvironmental evolution of the western Moesian carbonate platform: a case study from SW Bulgaria. Annales Societatis Geologorum Poloniae 78: 65-90.

Kaya M. Y. \& Altiner D. 2014. - Terebella lapilloides Münster, 1833 from the Upper Jurassic-Lower Cretaceous Inalti carbonates, northern Turkey: its taxonomic position and paleoenvironmentalpaleoecological significance. Turkish Journal of Earth Sciences 23: 166-183. https://doi.org/10.3906/yer-1306-2

KaYA M. Y. \& Altiner D. 2015. - Microencrusters from the Upper Jurassic-Lower Cretaceous Inalti Formation (Central Pontides, Turkey): remarks on the development of reefal/peri-reefal facies. Facies 61:18. https://doi.org/10.1007/s10347-015-0445-5

KaźmierCZAK J. \& Hillmer G. 1974. - Sclerosponge nature of the lower Hauterivian "bryozoan" Neuropora pustulosa (Roemer, 1839) from western Germany. Acta Palaeontologica Polonica 19: 443-453.

KERSHAW S. 1990. — Stromatoporoid palaeobiology and taphonomy in a Silurian biostrome on Gotland, Sweden. Palaeontology 33: 681-705.

Kershaw S. 2012. - Part E, Revised, Volume 4, Chapter 13: Paleoecology of the Paleozoic Stromatoporoidea. Treaties Online 3: 1-24. https://doi.org/10.17161/to.v0i0.4253

KERSHAW S. \& WeSt R. R. 1991. - Chaetetid growth form and its controlling factors. Lethaia 24: 333-346. https://doi. org/10.1111/j.1502-3931.1991.tb01483.x

KoŁodzIEJ B. 2003. - Late Jurassic chaetetids: a review and case study from the Holycross Mountains, Poland. Berichte des Institutes für Erdwissenschaften der Karl-Franzens-Universität Graz 7: 44. 
KoŁodziej B. 2015. — Corals of the Štramberk-type limestones from Poland: Taxonomic and palaeoecological aspects. Neues Jahrbuch für Geologie und Paläontologie Abhandlungen 276: 189-200.

KRAJEWSKI M. \& OlsZEWSKA B. 2006. - New data about microfacies and stratigraphy of the Late Jurassic Ay-Petri carbonate buildup (south-western Crimea Mountains, South Ukraine). Neues Jahrbuch für Geologie und Paläontologie Abhandlungen 5: 298-312. https://doi.org/10.1127/njgpm/2006/2006/298

KRAJEWSKI M. \& SCHLAGINTWEIT F. 2018. - Crescentiella-microbial-cement microframeworks in the Upper Jurassic reefs of the Crimean Peninsula. Facies 64: 21. https://doi.org/10.1007/ s10347-018-0534-3

LazĂr I., Grădinaru M. \& Petrescu L. 2013. — Ferruginous microstromatolites related to Middle Jurassic condensed sequences and hardgrounds (Bucegi Mountains, Southern Carpathians, Romania). Facies 59: 359-390. https://doi.org/10.1007/s10347012-0313-5

LEINFELDER R. R. 1993. - Upper Jurassic reef types and controlling factors-a preliminary report. Profil 5: 1-45.

LEINFELDER R. R. 2001. - Jurassic reef ecosystems, in STANLEY G. D. JR (ed), The Hystory and Sedimentology of Ancient Reef Systems. Topics in Geobiology 17: 251-309. https://doi. org/10.1007/978-1-4615-1219-6_8

Leinfelder R. R., Krautter M., Laternser R., Nose M., SChMid D. U., SChWeigert G., Werner W., KeUpp H., Brugger H., Herrmann R., Rehfeld-Kiefer U., Schroeder J. H., Reinhold C., Koch R., Zeiss A., SChweizer V., Christmann H., Menges G. \& LuterbaCHer H. 1994. - The origin of Jurassic reefs: current research developments and results. Facies 31: 1-56. https://doi.org/10.1007/BF02536932

Leinfelder R. R., SCHMid D. U., Nose M. \& Werner W. 2002. - Jurassic reef patterns-The expression o a changing globe, in Kiessling W., FlÜgel E. \& GolonKa J. (eds), Phanerozoic reef patterns. SEPM Special Publication 72: 465-520.

Leinfelder R. R., Schlagintweit F., Werner W., Ebli O., Nose M., SChmid D. U. \& Hughes G. W. 2005. - Significance of stromatoporoids in Jurassic reefs and carbonate platforms - concepts and implications. Facies 51: 287-325. https:// doi.org/10.1007/s10347-005-0055-8

Milan A. 1969. - Facijelni odnosi i Hidrozojska fauna Malmap rimorskog dijela sjevernog velebita i velike kapele. Geološki Vjesnik 22: 135-217.

MirCESCU C. V., BUCUR I. I. \& SăSĂRAN E. 2014. — Dasycladalean algae from Upper Jurassic-Lower Cretaceous limestones of Piatra Craiului Massif (South Carpathians, Romania) and their relationship to paleoenvironment. Studia Universitatis Babes-Bolyai: Geologia 59: 5-27. https://doi.org/10.5038/1937-8602.59.1.1

Mircescu C. V., Pleş G., Bucur I. I. \& Granier B. 2016. — JurassicCretaceous transition on the Getic carbonate platform (Southern Carpathians, Romania): Benthic foraminifera and algae. Carnets de Géologie 16: 491-512. https://doi.org/10.4267/2042/61824

Missoni S. \& GAWLICK H.-J. 2011. — Evidence for Jurassic subduction from Northern Calcareous Alps (Berchtesgaden; Austroalpine, Germany). International Journal of Earth Sciences 100: 605-1631. https://doi.org/10.1007/s00531-010-0552-z

Morsilli M. \& Bosellini A. 1997. — Carbonate facies zonation of the upper Jurassic-lower Cretaceous Apulia platform margin (Gargano Promontory, southern Italy). Rivista Italiana di Paleontologia e Stratigrafia 103: 193-206. https://doi. org/10.13130/2039-4942/5290

Nose M. \& Leinfelder R. R. 1997. - Upper Jurassic coral communities within siliciclastic settings (Lusitanian Basin, Portugal): implications for symbiotic and nutrient strategies. Proceedings of $8^{\text {th }}$ International Coral Reef Symposium, Panama City 2: 1755-1760.

Olivier N., Carpentier C., Bertrand M. G., Lathuilière M., Gaillard C., Ferry S., HantzPergue P. \& Geister J. 2004. Coral-microbialite reefs in pure carbonate versus mixed carbonate- siliciclastic depositional environments: the example of the Pagny-sur-Meuse section (Upper Jurassic, Northern France). Facies 50: 229-255. https://doi.org/10.1007/s10347-004-0018-5

PANAIOTU C. E., ANDRĂSANU A. \& VARBAN B. 1997. — Carbonate depositional facies from the Dâmbovicioara area (South, Piatra Craiului Massif) near the Jurassic-Cretaceous Boundary. Acta Palaeontologica Romaniae 1: 254-256.

Patrulius D. 1969. - Geologia Masivului Bucegi și a Culoarului Dâmbovicioara. Editura Academiei Republicii Socialiste România, București, $321 \mathrm{p}$.

PATRULIUS D. 1976. - Upper Jurassic-Lower Cretaceous carbonate rocks in the eastern part of the Getic Carbonate Platform and the adjacent flysch troughs, in PATRULIUS D., DRĂGĂNESCU A., Baltres A., Popescu B. \& RĂDAN S. (eds). - Carbonates Rocks and Evaporites-Guidebook. International Colloquium on Carbonates Rocks and Evaporites, Guidebook Series 15: 71-82.

Patrulius D. \& AVram E. 1976. - Stratigraphie et corrélations des terrains néocomiens et barrémo-bédouliens du couloir de Dâmbovicioara (Carpathes Orientales). Dări de seamă ale ședințelor - Institutul de Geologie și Geofizică 52: 135-160.

Patrulius D., Dimitrescu R. \& POPESCU I. 1971. - Geological Map of Romania. Sheet 110d. Institutul de Geologie și Geofizică. Ples G. \& Schlagintweit F. 2014. - New data on Perturbatacrusta leini Schlagintweit and Gawlick, 2011 (calcareous sponge?) from the Late Jurassic (Tithonian) of the Southern Carpathians, Romania. Acta Palaeontologica Romaniae 9: 7-13.

Pleș G., Mircescu C. V., Bucur I. I. \& SăsăRan E. 2013. Encrusting micro-organisms and microbial structures in Upper Jurassic limestones from the Southern Carpathians (Romania). Facies 59: 19-48. https://doi.org/10.1007/s10347-012-0325-1

Ples G., Bucur I. I. \& Păcurariu A. 2015. - Foraminiferal assemblages and facies associations in the Upper Jurassic carbonates from Ardeu Unit (Metaliferi Mountains, Romania). Acta Palaeontologica Romaniae 11: 43-57.

Pleș G., BuCur I. I. \& SăSĂRAN E. 2016. - Depositional environments, facies and diagenesis of the Upper Jurassic-Lower Cretaceous carbonate deposits of the Buila-Vânturarița Massif, Southern Carpathians (Romania). Annales Societatis Geologorum Poloniae 86: 165-183. https://doi.org/10.14241/asgp.2016.005

Pleș G., BÂrtaş T., Chelaru R. \& Bucur I. I. 2017. - Crescentiella morronensis (Crescenti) (incertae sedis) dominated microencruster association in Lower Cretaceous (lower Aptian) limestones from Rarău Massif (Eastern Carpathians, Romania). Cretaceous Research 79: 91-108. https://doi.org/10.1016/j. cretres.2017.07.015

Ples G., Oprișa A., Bucur I. I., Săsăran E., Mircescu C. V., Oltean G. \& IACOB R. G. 2019. - The central-western Getic Carbonate Platform: Upper Jurassic to Lower Cretaceous biostratigraphy and sedimentary evolution of the Cioclovina-Bănița sector (Sothern Carpathians, Romania). Facies 65: 32. https:// doi.org/10.1007/s10347-019-0574-3

ReITNER J. 1991. - Phylogenetic Aspects and New Descriptions of Spicule-Bearing Hadromerid Sponges with a Secondary Calcareous Skeleton (Tetractinomorpha, Demospongiae), in REITNER J. \& Keupp H. (eds), Fossil and Recent Sponges: 179-211. https://doi. org/10.1007/978-3-642-75656-6_15

REITNER J. 1992. — Coralline Spongien. Der Versuch einer phylogenetisch-taxonomischen Analyse. Berliner Geowissenschaftliche Abhandlungen 1: 1-356.

Ricci C., Rusciadelli G., Della Porta G., Lanfranchi A. JADOUL F. \& LATHUILIÈRE B. 2018. - Sedimentary evolution of a coral-, microbialites- and debris-rich Upper Jurassic reef (upper Tithonian, eastern Sardinia, Italy). Sedimentary Geology 376: 113-135. https://doi.org/10.1016/J.SEDGEO.2018.07.010

Rigby J. K. \& Senowbari-Daryan B. 1996. - Upper Permian Inozoid, Demospongid, and Hexactinellid Sponges from Djebel Tebaga, Tunisia. University of Kansas Paleontological Contributions (new series) 7: 1-130. 
Rusciadelli G., Ricci C. \& Lathuilière B. 2011. — The Ellipsactinia Limestones of the Marsica area (Central Apennines): a reference zonation model for Upper Jurassic Intra-Tethys reef complexes. Sedimentary Geology 233: 69-87. https://doi. org/10.1016/j.sedgeo.2010.10.011

RusSO A. \& MORSILlI M. 2007. - New insights on architecture and microstructure of Ellipsactinia and Sphaeractinia (demosponges) from the Gargano Promontory (southern Italy). Geologica Romana 40: 215-225.

SĂSĂRAN E. 2006. - Calcarele Jurasicului superior-Cretacicului inferior din Munții Trascău (in Romanian). Presa Universitară Clujeană, Cluj-Napoca, 249p.

SĂSĂRAN E., BUCUR I. I. \& PRICĂ I. 2001. - Microfacies and microfossils in Upper Jurassic limestones from Cheile Turenilor. Studia Universitatis Babeș-Bolyai: Geologia 46: 35-52. https://doi. org/10.5038/1937-8602.46.2.3

SCHLAgintWeit F. 2011. - Consinocodium japonicum Endo, 1961 from the Upper Jurassic of the Northern Calcareous Alps of Austria: not a siphonous green alga, but a coralline sponge. Revue de Paléobiologie 24: 533-540.

SCHLAGINTWEIT F. 2012. - Mohlerina basiliensis (Mohler, 1938): a Middle Jurassic-Early Cretaceous facultative (?) epilithic benthic foraminifer. Facies 58: 637-647. https://doi.org/10.1007/ s10347-012-0297-1

Schlagintweit F. \& Ebli O. 1999. - New results on microfacies, biostratigraphy and sedimentology of Late Jurassic-Early Cretaceous platform carbonates of the Northern Calcareous Alps. Part 1: Tressenstein Limestone, Plassen Formation. Abhandlungen der Geologischen Bundesanstalt 56: 379-418.

SChlagintWeIT F. \& GAWLICK H.-J. 2006. - Sarsteinia babai n. gen, n. sp., a new problematic sponge (inozoa?) form the Late Jurassic of the northern Calcareous Alps, Austria. Rivista Italiana di Paleontologia e Stratigrafia 112: 251-260.

SCHLAGINTWEIT F. \& GAWLICK H.-J. 2007. — Analysis of Late Jurassic to Early Cretaceous algal debris-facies of the Plassen carbonate platform in the Northern Calcareous Alps (Germany, Austria) and in the Kurbnesh area of the Mirdita zone (Albania): A tool to reconstruct tectonics and palaeogeography of eroded platforms. Facies 53: 209-227. https://doi.org/10.1007/s10347-006-0100-2

SCHLAGINTWEIT F. \& GAWLICK H.-J. 2008. — The occurrence and role of microencruster frameworks in Late Jurassic to Early Cretaceous platform margin deposits of the Northern Calcareous Alps (Austria). Facies 54: 207-231. https://doi.org/10.1007/ s10347-007-0131-3

SCHLAGINTWEIT F. \& GAWLICK H.-J. 2009. - Lituola? baculiformis n. sp., a new benthic foraminifer form Late Jurassic peri-refal carbonates of the Western Tethyan domain. Journal of Alpine Geology 51: 39-39.

SCHLaginTWEIT F. \& GAWLICK H.-J. 2011. - Perturbatacrusta leini n. gen., n. sp. a new microencruster incertae sedis (?sponge) from late Jurassic to earliest Cretaceous platform margin carbonates of the Northern Calcareous Alps of Austria. Facies 57: 123-135. https://doi.org/10.1007/s10347-010-0232-2

SCHLAGINTWEIT F., GAWLICK H.-J. \& LEIN R. 2005. — Mikropaläontologie und Biostratigraphie der Plassen-Karbonatplattform der Typlokalitat (Ober-Jura bis Unter-Kreide, Salzkammergut, Österreich). Journal of Alpine Geology 47: 11-102.
Schlagintweit F., Kadivar Z. \& Rashidi K. 2019. - Some microfossils (dasycladales, benthic foraminifera, sponges) from the Upper Jurassic Mozduran Formation (NE Iran, Kopet-Dagh) and their biostratigraphic and palaeobiogeographic importance. Rivista Italiana di Paleontologia e Stratigrafia 125:317-331. https:// doi.org/10.13130/2039-4942/11482

Schmid S. M., Bernoulli D., Fügenschuh B., Mațenco L., SCHefer S., SChuster R., Tischler M. \& UstasZewski K. 2008. - The Alpine-Carpathian-Dinaridic orogenic system: correlation and evolution of tectonic units. Swiss Journal of Geosciences 101: 139-183. https://doi.org/10.1007/s00015$008-1247-3$

Senowbari-Daryan B. \& Rigby J. K. 2011. — Part E, Revised, Volume 4, Chapter 7: Sphinctozoan and Inozoan Hypercalcified Sponges: An overview. Treatise Online 28: 1-90.

Termier G., Termier H. \& Ramalho M. 1985. — Spongiofaunes $\mathrm{du}$ Jurassique Superieur du Portugal. Comunicaçôes dos Serviços Geológicos de Portugal 71: 197-222.

TuRNŠEK D., BuSER S. \& OgOROLEC B. 1981. — An upper Jurassic reef complex from Slovenia, Yugoslavia, in TOOMEY D. F. (ed), European Fossil Reef Models. SEPM Special publication 30: 361369. https://doi.org/10.2110/pec.81.30.0361

Ungureanu R., SăSĂRAN E., Bucur I. I., Ungur C. G. \& MiRCESCU C. V. 2015. - The Berriasian-Valanginian and Aptian deposits from the north-western part of the Piatra Craiului Massif: stratigraphic relationships, facies and depositional environments. Acta Paleontologica Romaniae 11:59-74.

Ungureanu R., Săsăran E., Bucur I. I., Mircescu C. V., Ungur C. G. \& Ungureanu A. 2017. - The Cretaceous conglomerates from Piatra Craiului syncline (South Carpathians, Romania): searching for the source area. Facies 63: 30. https:// doi.org/10.1007/s10347-017-0512-1

Walter B. 1969. - Les bryozoaires jurassiques en France. Documents des Laboratoires de Géologie de la Faculté des Sciences de Lyon 35: 1-328.

Webby B. D. \& Kershaw S. 2011. - Part E, Revised, Volume 4 Chapter 9B: External morphology of the Paleozoic Stromatoporoidea: Shapes and growth habits. Treatise Online 25: 1-73. https://doi.org/10.17161/to.v0i0.4193

Werner W., Leinfelder R. R., FÜrsich F. T. \& Krautner M. 1994. - Comparative palaeoecology of marly coralline spongebearing reefal associations from the kimmeridgian (Upper Jurassic) of Portugal and Southwestern Germany. CFS Courier Forchungsinstitut Sencenberg 172: 381-397.

WEST R. R. 2011. - Part E, Revised, Volume 4, Chapter 2A: Introduction to the Fossil Hypercalcified Chaetetid-Type Porifera (Demospongiae). Treatise Online 20: 1-79.

West R. R., Vacelet J., Wood R., Willenz P. \& HartMAN W. D. 2013. - Part E, Revised, Volume 4, Chapter 4A-B: Hypercalcified extant and fossil chaetetid-type and Post-Devonian stromatoporoid-type Demospongiae: Systematic descriptions. Treatise Online 58: 1-95. https://doi. org/10.17161/to.v0i0.4447

WOOD R. 1987. - Biology and revised systematics of some late Mesozoic stromatoporoids. Special Papers in Paleontogy 37: 1-89.

Wood R. A. 1999. - Reef evolution. Oxford University Press, Oxford, $414 \mathrm{p}$. 